\title{
Naturally Occurring Compounds: New Potential Weapons against Oxidative Stress in Chronic Kidney Disease
}

\author{
Lorenzo Signorini ${ }^{\dagger}$, Simona Granata ${ }^{\dagger}$, Antonio Lupo and Gianluigi Zaza * \\ Renal Unit, Department of Medicine, University-Hospital of Verona, Verona 37126, Italy; \\ docsignorini88@gmail.com (L.S.); simona.granata@univr.it (S.G.); antonio.lupo@univr.it (A.L.) \\ * Correspondence: gianluigi.zaza@univr.it; Tel.: +39-045-812-2528; Fax: +39-045-802-7311 \\ + These authors contributed equally to this work.
}

Received: 31 May 2017; Accepted: 8 July 2017; Published: 10 July 2017

\begin{abstract}
Oxidative stress is a well-described imbalance between the production of reactive oxygen species (ROS) and the antioxidant defense system of cells and tissues. The overproduction of free radicals damages all components of the cell (proteins, lipids, nucleic acids) and modifies their physiological functions. As widely described, this condition is a biochemical hallmark of chronic kidney disease (CKD) and may dramatically influence the progression of renal impairment and the onset/development of major systemic comorbidities including cardiovascular diseases. This state is exacerbated by exposure of the body to uremic toxins and dialysis, a treatment that, although necessary to ensure patients' survival, exposes cells to non-physiological contact with extracorporeal circuits and membranes with consequent mitochondrial and anti-redox cellular system alterations. Therefore, it is undeniable that counteracting oxidative stress machinery is a major pharmacological target in medicine/nephrology. As a consequence, in recent years several new naturally occurring compounds, administered alone or integrated with classical therapies and an appropriate lifestyle, have been proposed as therapeutic tools for CKD patients. In this paper, we reviewed the recent literature regarding the "pioneering" in vivo testing of these agents and their inclusion in small clinical trials performed in patients affected by CKD.
\end{abstract}

Keywords: oxidative stress; reactive oxygen species; chronic kidney disease; antioxidants; nephrology

\section{Introduction}

Oxidative stress, a biochemical imbalance between reactive oxygen species (ROS) production and antioxidant defenses, has been reported as an important biochemical hallmark of several human diseases.

In chronic kidney disease (CKD), this deregulated biochemical machinery has been associated with disease progression and with the onset/development of severe systemic complications (mainly atherosclerosis and other cardiovascular diseases), with a consequent remarkable impact on major clinical outcomes [1-6].

Although present from the early stages of renal impairment, it appears severely enhanced with advancing stages of CKD and the start of renal replacement therapy (hemodialysis or peritoneal dialysis) [3].

Several biological factors are responsible for oxidative stress in this large population of patients, but, as recently described, mitochondrial deregulation seems to have a primary role [7-9].

Mitochondria are organelles with a major role in generating energy for cellular metabolism by the oxidative phosphorylation system (OXPHOS), and they are involved in several physiological cellular functions (e.g., ion homeostasis, heme and steroid synthesis, calcium signaling, apoptosis [10-13]). 
During CKD mitochondria may undergo a profound deregulation that can induce functional alterations. CKD is associated with a decline in mitochondrial content at the early stage of the disease [14].

In particular, during renal damage, continuous mitochondrial insults may activate a vicious functional circle responsible for an overproduction of ROS which can induce mitochondrial DNA mutations, damage the mitochondrial respiratory chain, alter membrane permeability, and influence $\mathrm{Ca}^{2+}$ homeostasis and mitochondrial defense systems. Mitochondrial dysfunction and renal failure are strictly connected: it has been demonstrated that the role of mitochondria in podocyte injury leads to proteinuria $[15,16]$ as well as epithelial to mesenchymal transition of tubular epithelial cells $[17,18]$. Moreover, uremic toxins impair OXPHOS in epithelial tubular cells [19].

Other biological factors contributing to oxidative stress in CKD are the enzymatic complex NADPH oxidase and the xanthine oxidase pathway. NADPH oxidase catalyzes the transfer of electrons to oxygen to produce superoxide anion $\left(\mathrm{O}_{2}{ }^{-}\right)$that is immediately converted to $\mathrm{H}_{2} \mathrm{O}_{2}$. These, in turn, are precursors of other ROS that cause damages to proteins, lipids, and nucleic acids [20]. NADPH oxidase-derived ROS are involved in cell signaling, ion channel activity, gene expression, and in the direct killing of invading microbes in phagocytes. Its activity is upregulated in all stages of CKD and in dialysis [21-23].

Xanthine oxidase catalyzes the oxidation of hypoxanthine to xanthine and xanthine to uric acid together with ROS release. Xanthine oxidase activity is higher in CKD patients [24] and could be an independent predictor of cardiovascular events in CKD and hemodialysis patients [25]. In this context, allopurinol, the xanthine oxidase inhibitor acting as a competitive substrate for the enzyme, decreases serum uric acid levels and its toxic effects [26]. Several studies have shown that allopurinol treatment decreases C-reactive protein (CRP) levels, slows the progression of renal disease, decreases the number of hospitalizations, and reduces cardiovascular risk [27-30]. However, since it is excreted by urine, it requires individual dosage modification in CKD patients, and consequently may have poor control over the serum concentration of uric acid [31,32]. In addition, systematic reviews have highlighted that allopurinol could have only a partial therapeutic efficacy, and may also induce adverse effects in CKD patients [33,34].

Febuxostat, an orally administered nonpurine selective inhibitor of xanthine oxidase with two excretion pathways (urinary and fecal), was more effective in the reduction and maintenance of serum urate levels $<6.0 \mathrm{mg} / \mathrm{dL}$ compared to allopurinol in patients with renal impairment [35-37].

At the same time, antioxidant systems are defective in CKD [38-41], but we recently described that nuclear factor erythroid 2-related factor 2 (NRF-2) and one of its target genes, superoxide dismutase (SOD) 2, are upregulated in dialysis-treated patients, defining a possible antioxidant system able to contrast ROS production.

Therefore, a worldwide interest is emerging in identifying and testing compounds able to significantly counteract oxidative damage in CKD. In particular, natural compounds targeting mitochondria, alone or combined with conventional therapies and lifestyle modifications, could represent valuable tools to prevent this condition and, because of the low adverse effects, they could be employed in patients undergoing both conservative and dialysis treatment [42].

These compounds are frequently included in the diet at biologically active concentrations and represent essential elements of traditional medicine from several countries. Although effective and relatively safety, they have been only partially investigated in nephrology and their efficacy in CKD is still debated.

To this purpose, a large number of studies have begun to address this objective by employing animal models and small clinical trials.

\section{L-Carnitine}

L-Carnitine (4-N-trimethylammonium-3-hydroxybutyric acid) is an amino acid-derived compound obtained mostly through the diet, particularly from animal-derived foods. It is 
endogenously synthesized in the kidney and liver from lysine and methionine, with a daily rate of $1.2 \mu \mathrm{mol} / \mathrm{kg} /$ day [43].

L-Carnitine acts as a transporter of long-chain fatty acids chains across the mitochondrial inner membrane, through a series of reversible transesterification reactions catalyzed by the group of carnitine acyltransferases. In these reactions, coenzyme A (CoA), bound to fatty acids, is substituted by the hydroxyl group of carnitine, forming acyl-carnitine. This molecule is transported from the cytosol to the inner mitochondrial matrix thanks to the combined activity of carnitine-acyl-carnitine translocase and carnitine palmitoyltransferase I and II. Here, acyl-carnitine is converted again into acyl-CoA, which can enter the $\beta$-oxidation and finally generate energy in the electron transport chain $[44,45]$.

Carnitine is thus fundamental for mitochondrial and cellular physiological activity. It has been demonstrated that its deficiency leads to (1) the accumulation of free fatty acids into cells; (2) impaired export of the excess of organic acids, particularly in some of the secondary carnitine insufficiencies, including hemodialysis; and (3) increased mitochondrial dysfunction and ROS production, secondary to acetyl-CoA accumulation and multiple enzymatic inhibition $[44,46]$.

Furthermore, carnitine acts as both a direct and indirect antioxidant by scavenging ROS, chelating iron [47], increasing the expression and activity of antioxidant enzymes [48], and by inhibiting lipid peroxidation and xanthine oxidase activity $[49,50]$.

$\mathrm{CKD}$ is characterized by a reduced synthesis of L-carnitine, proportional to the decline of the glomerular filtration rate (GFR). Nevertheless, its level is higher in CKD patients under conservative therapy than in healthy individuals, probably through a compensatory effect of the liver [51].

On the other hand, CKD patients undergoing hemodialysis (HD) and peritoneal dialysis (PD) show a reduction of free L-carnitine levels in plasma and muscle. This is due to several factors, including loss during dialysis treatment, intestinal malabsorption, and the impaired synthetic capacity of the kidney. In particular, Di Liberato et al. suggested a potential role of PD modality (CAPD) on carnitine depletion and the possible advantage of carnitine-containing dialysis fluids [52].

Due to its antioxidant role, the oral administration of L-carnitine to HD patients resulted in an increased glutathione (GSH) level, increased glutathione peroxidase activity, and a decreased malondyaldeide (MDA) level $[53,54]$. Interestingly, several reports have suggested that its supplementation might have a positive effect on the response to erythropoietin (EPO) in long-term hemodialysis patients [55-58], but it did not modify EPO requirements in patients new to hemodialysis [59].

During the past few years, some federal agencies have suggested the use of L-carnitine in HD. In 2003, the National Kidney Foundation developed a practice recommendation for the use of L-carnitine in patients with dialysis-related carnitine disorders, most notably erythropoietin-resistant anemia, intradialytic hypotension, cardiomyopathy, and fatigability [60]. However, KDOQI guidelines state that there is not sufficient evidence to recommend the administration of L-carnitine to HD patients with anemia [61].

Two important meta-analyses of the L-carnitine administration in HD patients were recently published, with controversial results. Chen et al. concluded that L-carnitine administration decreases serum low density lipoprotein (LDL) and CRP, while it fails to ameliorate EPO responsiveness and anemia [62]. In contrast Yang et al. did not find any conclusive evidence of effectiveness against inflammation, oxidative stress, anemia, nutrition, dyslipidemia, hyperparathyroidism, or quality of life in HD patients undergoing L-carnitine administration. These contrasting results suggest that additional long-term controlled randomized clinical trials are necessary to definitively understand the clinical utility of carnitine administration in CKD patients [63].

\section{Vitamin E}

Vitamin E encompasses a group of eight chemically related molecules, comprising $\alpha, \beta, \gamma, \delta$ tocopherol, and the derived tocotrienols [64]. The most biologically active form is $\alpha$-tocopherol [65]. The main sources of vitamin E are seed oils (wheat germ oil: $150 \mathrm{mg} / \mathrm{mL}$, almond oil: $95 \mathrm{mg} / \mathrm{mL}$, olive oil: $15 \mathrm{mg} / \mathrm{mL}$ ). 
$\alpha$-Tocopherol maintains the integrity of long-chain polyunsaturated fatty acids in the membranes of cells and thus preserves their bioactivity [66,67]. In particular, it protects lipid structures from peroxidation and increases LDL resistance to oxidative modification $[68,69]$, suggesting a potential effect of vitamin $E$ in the prevention of atherosclerosis [70,71].

Vitamin $\mathrm{E}$ is a powerful peroxyl radical scavenger that returns to its reduced state by reacting with vitamin C (or other hydrogen donors) [72].

Moreover, it reduces the mitochondrial generation of hydrogen peroxide and it regulates the expression of genes implicated in inflammation and fibrosis [73-76].

Although vitamin $\mathrm{E}$ therapy has been extensively studied in CKD patients, there is no consensus about the benefit obtained from its administration.

The SPACE study evaluated the cardiovascular protective effects of orally administered, high doses of vitamin E (800 IU/die) on HD patients with previous cardiovascular events, over a period of 519 days. The treatment resulted in a $40 \%$ decline in both composite cardiovascular events and myocardial infarction [77].

On the other hand, the administration of vitamin E (400 IU/day) to patients with mild to moderate renal failure failed to obtain beneficial effects on cardiovascular outcomes in the Heart Outcomes Prevention Evaluation (HOPE) study [78].

These contrasting results may be partially due to differences in the enrollment criteria (e.g., the SPACE trial included patients with higher cardiovascular risk, and participants were treated with a higher dose of vitamin E); moreover, most participants in the SPACE trial $(43.3 \%$ of the vitamin E group) also consumed vitamin C. Finally, the SPACE study enrolled a smaller sample (196 HD patients) compared with other trials, which resulted in large confidence intervals based on a broad composite end-point.

More recent studies have shown the positive effect of vitamin E administration before coronary procedures in the prevention of contrast-induced acute kidney injury in patients with CKD undergoing elective coronary procedures $[79,80]$.

Additionally, long-term use of vitamin E-coated HD filters improved oxidative stress, inflammatory markers, and hemoglobin levels, and reduced Erythropoiesis-Stimulating Agents (ESA) requirement without affecting dialysis adequacy [81-87].

Vitamin E combined with Pravastatin and homocysteine-lowering therapy was evaluated against vascular stiffness progression over 18 months in patients with mild to moderate CKD. This treatment resulted in significant improvement of vascular compliance and distensibility, decrement in common carotid intima-media thickness, and increase in brachial artery flow-mediated dilatation; however, the effect of other confounding variables was unclear $[88,89]$.

It is noteworthy that vitamin E could have also a pro-oxidant action under special conditions that can be encountered in HD patients [90,91]. In fact, oral $\alpha$-tocopherol administration ( $500 \mathrm{mg} /$ day) for 1 year to HD patients caused reduced SOD activity and total antioxidant status [91]. This could be due to the low level of other antioxidants necessary to restore the reduced form of vitamin E (e.g., vitamin C) [92].

Based on research studies, vitamin E supplementation could be a potential valuable adjuvant therapy to contrast oxidative stress and lower lipid peroxidation in CKD and HD patients. Still, because of its adverse effects [93], its clinical employment in nephrology needs to be better defined.

\section{Vitamin C}

Vitamin C (ascorbic acid) is a water-soluble essential antioxidant obtained from citrus fruits and some green vegetables such as broccoli and spinach [94]. Its recommended daily dose is approximately $90 \mathrm{mg}$ in adult men and $75 \mathrm{mg}$ in adult women [95].

Vitamin C prevents oxidative damage by scavenging ROS and reactive nitrogen species [96]. Moreover, it shows an anti-apoptotic activity by maintaining the mitochondrial membrane potential and protecting mitochondrial DNA from oxidant insults [97-100]. 
It has been demonstrated that a reduction in both the total vitamin $C$ concentration and the active form (ascorbate) is probably caused by the limited intake of potassium-rich foods in CKD patients in conservative treatment, and by the loss during HD treatment. Another possible explanation is an impairment of enzymatic or non-enzymatic recycling of ascorbate from dehydroascorbate (the oxidized form of vitamin C), since the recycling is largely GSH-dependent [101] and dialysis patients have a marked GSH deficiency [102,103]. The low vitamin C plasma levels in CKD patients has been, then, associated with an increased risk for fatal and nonfatal major adverse cardiovascular events [104,105].

To avoid this condition, currently oral ascorbate (1-1.5 g/week) or parenteral ascorbate (300 mg/dialysis session) are suggested to balance subclinical deficiency [103].

Poly-vitamin supplementation, including vitamin C ( $250 \mathrm{mg}$ /day), for eight weeks to HD patients did not induce any change in inflammation, malnutrition, or oxidative stress markers [106].

Moreover, in a double-blind randomized clinical trial on CKD patients (stage IV-V and HD), vitamin C ( $250 \mathrm{mg}$, three times a week) failed to demonstrate a real clinical benefit when evaluated against uremic symptoms and cardiovascular stability [107].

Conversely, several studies showed advantages of vitamin C administration. In a cross-over study, patients treated for three months with vitamin C ( $200 \mathrm{mg} /$ day) showed decreased CRP levels and increased serum prealbumin concentration as marker of malnutrition [108]. Interestingly, the use of vitamin E-coated dialysis membranes significantly reduced oxidative stress, avoided a reduction of erythrocyte reductases activity, and decreased the level of proinflammatory cytokines [81]. Moreover, other studies reported that this vitamin improved the response to ESA with a significant enhancement of hemoglobin levels and transferrin saturation [109,110]. At the moment, despite encouraging results from clinical research studies, the use of vitamin $C$ is still debated in nephrology.

\section{Coenzyme Q10}

Coenzyme Q10 (CoQ10) is a high lipophilic molecule diffuse in eukaryotic cells that is mostly concentrated in mitochondria, as component of the mitochondrial respiratory chain where it transports electrons from complex I/II to complex III [111].

It is synthesized in the human body and is assumed with food (animal muscle and liver, blue fish, soy beans, and olive oil) with an estimated daily intake of 3-6 mg [112].

Due to its abundant distribution and intra-membranous localization, CoQ10 prevents membrane lipid peroxidation since hydroxyl and superoxide radicals generated in the membrane during electron transport chain would otherwise rapidly react with neighboring lipid and protein molecules [113,114].

CoQ10 regenerates vitamin E from the $\alpha$-tocopheroxyl radical and prevents the oxidation of nucleic acids, particularly of mitochondrial DNA [113]. Additionally, it inhibits mitochondriadependent apoptosis by preventing permeability transition pore opening and mitochondrial membrane potential depolarization [111,115]. Moreover, increased mitochondrial CoQ10 content results in a general improvement of bioenergetic parameters, such as oxygen consumption, ATP content, mitochondrial potential, and protein synthesis [116].

As a consequence, CoQ10 has been studied in clinical settings in order to prevent atherosclerosis, aging, and the progression of chronic diseases such as CKD.

In CKD patients, it an inverse relationship between CoQ10 and renal function has been reported $[117,118]$.

An interesting correlation was also demonstrated between reduced CoQ10 levels and epicardial fat tissue (EFT) in HD patients [119]. EFT is the visceral adipose tissue surrounding the subepicardial coronary vessels. It is an active source of proinflammatory factors [120-122], and, in greater amounts, has recently been related to a higher risk for atherosclerosis and heart disease in PD and HD patients $[123,124]$. Thus, increased EFT in HD patients could cause the consumption of CoQ10 as an antioxidant molecule, and its supplementation was hypothesized able to correct this imbalance, reducing cardiovascular risk. 
In a recent trial involving patients in maintenance HD, oral CoQ10 (200 mg/day) supplementation did not induce changes in exercise performance and in the blood level of oxidative system markers compared with a placebo [125].

As with other similar compounds, at present, there is no a clear evidence that justifies the "day by day" clinical employment of CoQ10 in CKD patients in both conservative and dialysis treatment.

\section{6. $\alpha$-Lipoic Acid}

$\alpha$-Lipoic acid (ALA) is a disulfide compound that acts as a coenzyme in pyruvate dehydrogenase and $\alpha$-ketoglutarate dehydrogenase mitochondrial reactions [126]. Typical dietary sources of ALA are muscle meats, heart, kidney, and liver, and to a lesser degree, fruits and vegetables [127].

ALA and its reduced form, dihydrolipoic acid, have several antioxidant, anti-inflammatory, and metabolic activities.

ALA exerts direct antioxidant activity by chelating $\mathrm{Cu}^{2+}, \mathrm{Zn}^{2+}$, and $\mathrm{Fe}^{2+}[128,129]$, and it recycles other cellular antioxidants including CoQ10, vitamins C and E, and GSH. It also regulates the expression of numerous genes trough the inhibition of NFkB [130] and the induction of NRF2 [131].

As a modulator of peroxisome proliferator-activated receptor (PPAR)- $\alpha$ and $-\gamma$ expression, ALA is implied in the regulation of glucose and lipid metabolism [131].

Moreover, it inhibits vascular calcification and vascular smooth muscle cell apoptosis by preserving mitochondrial functions and activating the PI3K/Akt pathway [132].

In a model of diabetic nephropathy, it reduced the progression of renal damage, glomerular mesangial matrix expansion, and glomerulosclerosis by restoring GSH, reducing MDA levels, and protecting mitochondrial function [133,134].

However, ALA supplementation in hemodialyzed patients showed uncertain results. A daily dose of $600 \mathrm{mg}$ for eight weeks caused a reduction of CRP levels, without showing effects on MDA, total antioxidant status, total cholesterol, triglyceride, high-density lipoprotein cholesterol, or LDL levels [135]. Contrarily, in other studies, ALA combined with mixed tocopherols did not modify the level of several biomarkers of inflammation and oxidative stress [136-139].

Further studies, probably using mixed antioxidants and longer courses of treatment, could be useful to demonstrate the clinical utility of ALA supplementation in this patient population.

\section{Selenium}

Selenium is a non-metal element essential for human physiology, since it acts as a cofactor for several enzymes with an antioxidant role (glutathione peroxidase, thioredoxin reductase) [140]. It is obtained from meat, seafood, grains, cereals, fish (tuna and mackerel), and plants (garlic, onions, and broccoli), but the best source of selenium is Brazil nuts [141].

Several reports have demonstrated a selenium deficiency in CKD and dialyzed patients [142-145].

In patients with $C K D$, selenium supplementation increased the glutathione peroxidase activity [146], but unfortunately, this positive effect was detectable only if this agent was administered in the early stages of renal impairment [147].

Selenium supplementation $(200 \mu \mathrm{g})$ for 12 weeks prevents the damage of DNA [148] and improved MDA levels [149], without showing any significant effects on inflammatory and thyroid functional biomarkers [150].

Moreover, $600 \mu \mathrm{g}$ sodium selenide co-administered with $400 \mathrm{IU}$ vitamin E before an HD session offsets the serum MDA increment induced by iron infusion [151].

At the moment, there is no indication to the use of selenium in CKD and additional, larger clinical studies are necessary to define its future potential employment in this clinical setting.

\section{Green Tea}

Green tea is composed of several polyphenolic compounds, but (-)-Epigallocatechin-3-gallate (EGCG) is the most abundant and effective as an antioxidant [152]. In fact, it is implicated in ROS 
scavenging, the inhibition of lipid peroxidation, and the chelation of metal ions such as copper (II) and iron (III) [153-156].

Recently these protective properties have become of interest specifically in kidney diseases, and EGCG has been tested in several animal models of glomerulonephritis [157]. Treatment with EGCG reduced proteinuria and serum creatinine, and it determined a marked improvement in several renal histological features. These effects seemed to be mediated by the direct and indirect effects of these agents on the redox cellular/biological system and the immune-inflammatory pathway [158-160]. In particular, EGCG increased renal NRF2 and glutathione peroxidase activity; reduced renal oxidative stress, NF-KB activation, and NLRP3 mRNA/protein expression as well as protein levels of mature caspase-1, IL-1 $\beta$, and IL-18; and enhanced splenic regulatory T cell activity. EGCG-treated mice also showed a reduction in p-Akt, p-JNK, p-ERK1/2, and p-P38 as well as the restoration of peroxisome proliferator-activated receptor (PPAR) $\gamma$ and sirtuin-1 (SIRT1) levels [158-160].

In streptozotocin-induced diabetic nephropathy, EGCG administration for 50 days improved renal function as well as reduced renal AGE accumulation, lipid peroxidation, and fibronectin levels [161].

In animal models of unilateral urethral obstruction, EGCG caused the upregulation and nuclear translocation of NRF2, with the consequent enhancement of antioxidant enzymes such as $\gamma$-glutamylcysteine synthetase [162].

EGCG significantly reduced uremic toxins, such as methylguanidine levels, in a dose-dependent manner in rats with adenine-induced renal failure [163].

In an ischemia reperfusion injury model, EGCG treatment, via monocyte chemoattractant protein-1 (MCP-1) and transforming growth factor (TGF- $\beta$ ) downregulation and heme oxygenase 1 (HO-1) augmentation, protected the kidneys from a massive infiltration of macrophages [164] and the development of chronic renal alterations.

It must be noted, however, that all of the abovementioned studies are speculative and no large clinical trials have been published in nephrology.

\section{Resveratrol}

Resveratrol (3,5,4'-trihydroxystilbene) is a naturally occurring polyphenolic compound present in more than 70 species of plants, with the greatest amount found in grapes, berries, red wine, and peanuts [165].

Resveratrol can directly scavenge ROS and modulate the expression and activity of antioxidant enzymes such as SOD, glutathione peroxidase, and catalase, through transcriptional regulation via NRF-2, activator protein 1 (AP-1), forkhead box O (FOXO), and SP-1 [166,167]. Moreover, it is an activator of SIRT1, an NAD ${ }^{+}$-dependent deacetylase of histones, which results in reduced transcriptional activity. SIRT1 plays a key role in responding to nutritional and environmental perturbations such as fasting, calorie restriction, starvation, and nutrient deprivation, as well as in oxidative stress conditions $[168,169]$. SIRT1 activates peroxisome proliferator-activated receptor gamma coactivator 1- $\alpha$ (PGC-1 $\alpha$ ) and attenuates sterol-regulatory-element-binding protein (SREBP) activity, resulting in increased fatty acid oxidation, reduced lipogenesis and cholesterolgenesis, and improved glucose homeostasis and mitochondrial function [170,171]. Moreover, it deacetylates FOXO, p53, hypoxia-inducible factor (HIF)- $1 \alpha$, and NFkB, mediating antiapoptotic, antioxidative, and anti-inflammatory effects [172,173].

Due to its cytoprotective effects, resveratrol has been largely tested in animal models of chronic renal diseases. In streptozotocin-induced diabetic rats, resveratrol ( 5 or $10 \mathrm{mg} / \mathrm{kg}$ administered orally) improved renal dysfunction and oxidative stress, and attenuated cytokine levels [174,175].

Resveratrol, then, seemed to prevent in vitro high glucose-induced mesangial cell proliferation and fibronectin expression by inhibiting JNK and NF- KB, as well as NADPH oxidase activity and ROS production [176]. These results were in line with more recent studies that demonstrated a positive effect of this agent in podocytes of $\mathrm{db} / \mathrm{db}$ mice through the activation of the autophagic pathway [177]. 
Resveratrol, through its antioxidant mechanisms and the deacetylation of Smad3, directly prevents EMT and renal fibrosis [176,178-181], and inhibits CKD-induced skeletal muscle atrophy mediated by NF-KB [182].

Moreover, by enhancing the AMPK/SIRT-1/PGC-1 $\alpha$ axis [183] this agent could attenuate mitochondrial dysfunction and aldosterone-induced podocyte injury [184].

In other animal models of AKI (cisplatin nephropathy, ischemia-reperfusion, and sepsis-related acute renal damages), resveratrol demonstrated a considerable renal protective effect by normalizing Nrf2 renal expression, enhancing antioxidant factors expression (HO-1, GST), and reducing inflammatory mediators (TNF- $\alpha$, IL-6) [185-187].

Unfortunately, although resveratrol has demonstrated low adverse effects, no study has been developed to evaluate its efficacy in CKD patients, probably because its low bioavailability [188]. In the future, the employment of this agent in combination with other compounds could probably permit its use to counteract the progression to end-stage renal disease.

\section{Curcumin}

Curcumin is the active element of curcuma longa (or turmeric), a perennial herbaceous plant member of the ginger family (Zingiberaceae), prevalent in India, China, and Southeast Asia [189].

In Ayurvedic and Chinese medicine, curcumin is used as anti-inflammatory, antioxidant, antibacterial, and antimicrobial reagent, as well as to treat chronic diseases [190-194].

Its antioxidant properties are due to both a direct scavenger activity and the upregulation of antioxidant and cytoprotective genes. Curcumin is able to directly scavenge superoxide anions, hydroxyl radicals, $\mathrm{H}_{2} \mathrm{O}_{2}$, singlet oxygen, nitric oxide, and peroxynitrite [195-198], probably by means of phenolic groups in its molecular structure. Curcumin also has an indirect antioxidant ability mediated by the induction of the expression of cytoprotective enzymes such as SOD, catalase [199], glutathione reductase, HO-1 [200], glutathione S-transferase, NAD(P)H:quinone oxidoreductase 1 [201], and $\gamma$-glutamylcysteine ligase [202].

Several studies have reported the reno-protective effects of curcumin in a mouse model of diabetic nephropathy. Administration of curcumin (15-150 mg/kg/day for two to eight weeks) ameliorated renal function through the upregulation of antioxidant enzymes, inhibition of NADPH oxidase and $\mathrm{NFkB}$, and it reduced macrophages infiltration and proinflammatory cytokines together with antifibrotic activities [203-207].

Likewise, in an animal model of CKD, curcumin significantly reversed proteinuria, hypertension, interstitial fibrosis, fibrotic glomeruli, tubular atrophy, and mesangial expansion [208-213]. Interestingly, the preservation of mitochondrial dynamics, bioenergetics, and oxidative stress has been recently demonstrated in a rat model of CKD, which may be associated with ameliorated renal function [214].

Moreover, curcumin improved structural and functional manifestations of cardiac injury associated with renal failure, in part through the inhibition of NLRP3 inflammasome and the preservation of mitochondrial function [215-217].

Khajehdehi et al. showed that an oral supplementation of $500 \mathrm{mg}$ turmeric (of which $22.1 \mathrm{mg}$ was the active ingredient curcumin) for three months has strong renal protective effects in lupus nephritis and type 2 diabetic nephropathies [218,219].

However, although it is a promising agent for the treatment of chronic glomerulopathies and tubular renal dysfunctions, at the moment, the clinical evidences are not adequate to justify a large utilization of this compound in our nephrology patients.

\section{Omega-3 Polyunsaturated Fatty Acids}

Omega-3 polyunsaturated fatty acids (omega-3 PUFAs) are a class of essential long-chain fatty acids obtained primarily from dietary sources.

The two most bioactive and extensively studied omega- 3 fatty acids are eicosapentaenoic acid (EPA) and docosahexaenoic acid (DHA) [220]. 
Omega-3 PUFAs exert anti-inflammatory activity by modifying the expression of adhesion molecules, chemotactic factors, and proinflammatory cytokines (TNF- $\alpha$, IL-1 $\beta$, and IL-6) [221-224].

Another mechanism is the prevention of the conversion of arachidonic acid into proinflammatory eicosanoids such as prostaglandin (PG) and leukotriene (LT) [225], and serving as an alternative substrate to produce less potent 5-series LTs, 3-series PGs, and thromboxanes [226]. In addition, omega-3 PUFA-derived resolvins such as resolvin E1 (RvE1) and D-series resolvins and protectin D1 from DHA have potent anti-inflammatory actions [227,228].

These compounds maintain the structure and function of cell and organelle membranes [229], participating in membrane fluidity, ion channels transport (sodium, potassium, and calcium) [230], and mitochondrial biogenesis [231].

In addition to anti-inflammatory properties, omega-3 fatty acids also have antioxidant effects.

They enhance endogenous antioxidant defense systems such as GSH through the increased activity of $\gamma$-glutamyl-cysteinyl ligase, glutathione reductase, and glutathione $S$-transferase [232], and compete with arachidonic acid at COX2 and xanthine oxidase sites, reducing ROS synthesis [233].

In animal models of CKD, EPA and DHA supplementation reduce inflammation, fibrosis, and oxidative stress [234-236].

In CKD and dialysis patients, the administration of omega-3 PUFAs can reduce inflammation associated with CKD progression through the upregulation of E- and D-series resolvins [237], together with the reduced level of endothelial chemokines, RANTES, and MCP-1 [238].

At the same time, recent studies suggest a benefit of omega-3 PUFAs supplementation in ameliorating uremic symptoms (particularly pruritus) [239] and reducing hypertension [240,241].

In a randomized controlled clinical trial on 78 patients affected by IgA nephropathy, PUFAs associated with renin-angiotensin system blockers were more effective than renin-angiotensin system blockers alone in reducing proteinuria. Unfortunately, the small number of patients, the short time of observation (six months) and the single-center nature of the study limits the power of these conclusions [242].

Because of the few strong evidences of its benefit in CKD, additional studies are warranted to assess the real efficacy of these agents in slowing the progression of renal failure and to establish the formal intake recommendations and dosing in the CKD patient population (particularly in dialysis).

\section{Conclusions}

CKD is associated with enhanced oxidative stress that is a well-known risk factor for the onset/development of severe systemic complications and cardiovascular diseases. Several studies report a higher level of oxidative stress markers together with reduced antioxidants in pre-dialysis patients. This condition is exacerbated during the progression of renal failure and in renal replacement therapy. Several biological mechanisms contribute to oxidative stress, including mitochondrial activity, xanthine oxidase, and NADPH oxidase. Thus, in recent years the administration of antioxidants, both food-derived and through drugs with additional antioxidant effects, have demonstrated positive effects. Many of these compounds have direct ROS scavenger properties due to their molecular structure (L-carnitine, vitamin E, vitamin C, $\alpha$-lipoic acid, green tea, resveratrol, curcumin), others also have indirect antioxidant effects mediated by the upregulation of antioxidant enzymes (L-carnitine, green tea, $\alpha$-lipoic acid, resveratrol, curcumin) or by additional anti-inflammatory properties (vitamin E, resveratrol, curcumin, omega-3).

However, the great limit of most of these studies is the low sample size and short-term follow-up. As a consequence, none of these molecules have been introduced into usual clinical practice. Therefore, future prospective and comparative studies analyzing the co-administration of different antioxidants with long-term follow-up are warranted.

Author Contributions: Lorenzo Signorini, Simona Granata and Gianluigi Zaza searched the literature and wrote the manuscript; Antonio Lupo revised the manuscript; All authors read and approved the final manuscript.

Conflicts of Interest: The authors declare no conflict of interest. 


\section{References}

1. Cachofeiro, V.; Goicochea, M.; de Vinuesa, S.G.; Oubiña, P.; Lahera, V.; Luño, J. Oxidative stress and inflammation, a link between chronic kidney disease and cardiovascular disease. Kidney Int. Suppl. 2008, 111, S4-S9. [CrossRef] [PubMed]

2. Dounousi, E.; Papavasiliou, E.; Makedou, A.; Ioannou, K.; Katopodis, K.P.; Tselepis, A.; Siamopoulos, K.C.; Tsakiris, D. Oxidative stress is progressively enhanced with advancing stages of CKD. Am. J. Kidney Dis. 2006, 48, 752-760. [CrossRef] [PubMed]

3. Dursun, B.; Dursun, E.; Suleymanlar, G.; Ozben, B.; Capraz, I.; Apaydin, A.; Ozben, T. Carotid artery intima-media thickness correlates with oxidative stress in chronic haemodialysis patients with accelerated atherosclerosis. Nephrol. Dial. Transplant. 2008, 23, 1697-1703. [CrossRef] [PubMed]

4. Kato, A.; Odamaki, M.; Hishida, A. Blood 8-hydroxy-2'-deoxyguanosine is associated with erythropoietin resistance in hemodialysis patients. Nephrol. Dial. Transplant. 2003, 18, 931-936. [CrossRef] [PubMed]

5. Del Vecchio, L.; Locatelli, F.; Carini, M. What we know about oxidative stress in patients with chronic kidney disease on dialysis-Clinical effects, potential treatment, and prevention. Semin Dial. 2011, $24,56-64$. [CrossRef] [PubMed]

6. Locatelli, F.; Canaud, B.; Eckardt, K.; Stenvinkel, P.; Wanner, C.; Zoccali, C. Oxidative stress in end-stage renal disease: An emerging treat to patient outcome. Nephrol. Dial. Transplant. 2003, 18, 1272-1280. [CrossRef]

7. Granata, S.; Zaza, G.; Simone, S.; Villani, G.; Latorre, D.; Pontrelli, P.; Carella, M.; Schena, F.P.; Grandaliano, G.; Pertosa, G. Mitochondrial dysregulation and oxidative stress in patients with chronic kidney disease. BMC Genom. 2009, 10, 388. [CrossRef] [PubMed]

8. Zaza, G.; Granata, S.; Masola, V.; Rugiu, C.; Fantin, F.; Gesualdo, L.; Schena, F.P.; Lupo, A. Downregulation of nuclear-encoded genes of oxidative metabolism in dialyzed chronic kidney disease patients. PLoS ONE 2013, 8, e77847. [CrossRef]

9. Granata, S.; Masola, V.; Zoratti, E.; Scupoli, M.T.; Baruzzi, A.; Messa, M.; Sallustio, F.; Gesualdo, L.; Lupo, A.; Zaza, G. NLRP3 inflammasome activation in dialyzed chronic kidney disease patients. PLoS ONE 2015, 10, e0122272. [CrossRef] [PubMed]

10. Hajnóczky, G.; Csordás, G.; Das, S.; Garcia-Perez, C.; Saotome, M.; Sinha Roy, S. Mitochondrial calcium signalling and cell death: Approaches for assessing the role of mitochondrial $\mathrm{Ca}^{2+}$ uptake in apoptosis. Cell Calcium 2006, 40, 553-560. [CrossRef] [PubMed]

11. Ajioka, R.S.; Phillips, J.D.; Kushner, J.P. Biosynthesis of heme in mammals. Biochim. Biophys. Acta 2006, 1763, 723-736. [CrossRef] [PubMed]

12. Rossier, M.F. T channels and steroid biosynthesis: In search of a link with mitochondria. Cell Calcium 2006, 40, 155-164. [CrossRef] [PubMed]

13. Green, D.R. Apoptotic pathways: The roads to ruin. Cell 1998, 94, 695-698. [CrossRef]

14. Gamboa, J.L.; Billings, F.T.; Bojanowski, M.T.; Gilliam, L.A.; Yu, C.; Roshanravan, B.; Roberts, L.J.; Himmelfarb, J.; Ikizler, T.A.; Brown, N.J. Mitochondrial dysfunction and oxidative stress in patients with chronic kidney disease. Physiol. Rep. 2016, 4, e12780. [CrossRef] [PubMed]

15. Su, M.; Dhoopun, A.R.; Yuan, Y.; Huang, S.; Zhu, C.; Ding, G.; Liu, B.; Yang, T.; Zhang, A. Mitochondrial dysfunction is an early event in aldosterone-induced podocyte injury. Am. J. Physiol. Ren. Physiol. 2013, 305, F520-F531. [CrossRef] [PubMed]

16. Zhao, M.; Yuan, Y.; Bai, M.; Ding, G.; Jia, Z.; Huang, S.; Zhang, A. PGC-1 $\alpha$ overexpression protects against aldosterone-induced podocyte depletion: Role of mitochondria. Oncotarget 2016, 7, 12150-12162. [PubMed]

17. Yuan, Y.; Chen, Y.; Zhang, P.; Huang, S.; Zhu, C.; Ding, G.; Liu, B.; Yang, T.; Zhang, A. Mitochondrial dysfunction accounts for aldosterone-induced epithelial-to-mesenchymal transition of renal proximal tubular epithelial cells. Free Radic Biol. Med. 2012, 53, 30-43. [CrossRef] [PubMed]

18. Zhang, A.; Jia, Z.; Guo, X.; Yang, T. Aldosterone induces epithelial-mesenchymal transition via ROS of mitochondrial origin. Am. J. Physiol. Ren. Physiol. 2007, 293, F723-F731. [CrossRef] [PubMed]

19. Mutsaers, H.A.; Wilmer, M.J.; Reijnders, D.; Jansen, J.; van den Broek, P.H.; Forkink, M.; Schepers, E.; Glorieux, G.; Vanholder, R.; van den Heuvel, L.P.; et al. Uremic toxins inhibit renal metabolic capacity through interference with glucuronidation and mitochondrial respiration. Biochim. Biophys. Acta 2013, 1832, 142-150. [CrossRef] [PubMed] 
20. Sedeek, M.; Nasrallah, R.; Touyz, R.M.; Hébert, R.L. NADPH oxidases, reactive oxygen species, and the kidney: Friend and foe. J. Am. Soc. Nephrol. 2013, 24, 1512-1518. [CrossRef] [PubMed]

21. Vaziri, N.D.; Dicus, M.; Ho, N.D.; Boroujerdi-Rad, L.; Sindhu, R.K. Oxidative stress and dysregulation of superoxide dismutase and NADPH oxidase in renal insufficiency. Kidney Int. 2003, 63, 179-185. [CrossRef] [PubMed]

22. Fortuño, A.; Beloqui, O.; San José, G.; Moreno, M.U.; Zalba, G.; Díez, J. Increased phagocytic nicotinamide adenine dinucleotide phosphate oxidase-dependent superoxide production in patients with early chronic kidney disease. Kidney Int. Suppl. 2005, 99, S71-S75. [CrossRef] [PubMed]

23. Morena, M.; Cristol, J.P.; Senécal, L.; Leray-Moragues, H.; Krieter, D.; Canaud, B. Oxidative stress in hemodialysis patients: Is NADPH oxidase complex the culprit? Kidney Int. Suppl. 2002, 80, 109-114. [CrossRef] [PubMed]

24. Choi, J.Y.; Yoon, Y.J.; Choi, H.J.; Park, S.H.; Kim, C.D.; Kim, I.S.; Kwon, T.H.; Do, J.Y.; Kim, S.H.; Ryu, D.H.; et al. Dialysis modality-dependent changes in serum metabolites: Accumulation of inosine and hypoxanthine in patients on haemodialysis. Nephrol. Dial Transplant. 2011, 26, 1304-1313. [CrossRef] [PubMed]

25. Gondouin, B.; Jourde-Chiche, N.; Sallee, M.; Dou, L.; Cerini, C.; Loundou, A.; Morange, S.; Berland, Y.; Burtey, S.; Brunet, P.; et al. Plasma Xanthine Oxidase Activity Is Predictive of Cardiovascular Disease in Patients with Chronic Kidney Disease, Independently of Uric Acid Levels. Nephron 2015, 131, 167-174. [CrossRef] [PubMed]

26. Small, D.M.; Gobe, G.C. Oxidative Stress and Antioxidant Therapy in Chronic Kidney and Cardiovascular Disease. In Oxidative Stress and Chronic Degenerative Diseases-A Role for Antioxidants; In Tech: Vienna, Austria, 2013.

27. Goicoechea, M.; de Vinuesa, S.G.; Verdalles, U.; Ruiz-Caro, C.; Ampuero, J.; Rincón, A.; Arroyo, D.; Luño, J. Effect of allopurinol in chronic kidney disease progression and cardiovascular risk. Clin. J. Am. Soc. Nephrol. 2010, 5, 1388-1393. [CrossRef] [PubMed]

28. Siu, Y.P.; Leung, K.T.; Tong, M.K.; Kwan, T.H. Use of allopurinol in slowing the progression of renal disease through its ability to lower serum uric acid level. Am. J. Kidney Dis. 2006, 47, 51-59. [CrossRef] [PubMed]

29. Kanbay, M.; Ozkara, A.; Selcoki, Y.; Isik, B.; Turgut, F.; Bavbek, N.; Uz, E.; Akcay, A.; Yigitoglu, R.; Covic, A. Effect of treatment of hyperuricemia with allopurinol on blood pressure, creatinine clearence, and proteinuria in patients with normal renal functions. Int. Urol. Nephrol. 2007, 39, 1227-1233. [CrossRef] [PubMed]

30. Goicoechea, M.; Garcia de Vinuesa, S.; Verdalles, U.; Verde, E.; Macias, N.; Santos, A.; Pérez de Jose, A.; Cedeño, S.; Linares, T.; Luño, J. Allopurinol and progression of CKD and cardiovascular events: Long-term follow-up of a randomized clinical trial. Am. J. Kidney Dis. 2015, 65, 543-549. [CrossRef] [PubMed]

31. Becker, M.A.; Schumacher, H.R., Jr.; Wortmann, R.L.; MacDonald, P.A.; Eustace, D.; Palo, W.A.; Streit, J.; Joseph-Ridge, N. Febuxostat compared with allopurinol in patients with hyperuricemia and gout. N. Engl. J. Med. 2005, 353, 2450-2561. [CrossRef] [PubMed]

32. Dalbeth, N.; Kumar, S.; Stamp, L.; Gow, P. Dose adjustment of allopurinol according to creatinine clearance does not provide adequate control of hyperuricemia in patients with gout. J. Rheumatol. 2006, 33, 1646-1650. [PubMed]

33. Thurston, M.M.; Phillips, B.B.; Bourg, C.A. Safety and efficacy of allopurinol in chronic kidney disease. Ann. Pharmacother. 2013, 47, 1507-1516. [CrossRef] [PubMed]

34. Fleeman, N.; Pilkington, G.; Dundar, Y.; Dwan, K.; Boland, A.; Dickson, R.; Anijeet, H.; Kennedy, T.; Pyatt, J. Allopurinol for the treatment of chronic kidney disease: A systematic review. Health Technol. Assess. 2014, 18, 1-77. [CrossRef] [PubMed]

35. Schumacher, H.R., Jr.; Becker, M.A.; Wortmann, R.L.; Macdonald, P.A.; Hunt, B.; Streit, J.; Lademacher, C.; Joseph-Ridge, N. Effects of febuxostat versus allopurinol and placebo in reducing serum urate in subjects with hyperuricemia and gout: A 28-week, phase, I.I.I.; randomized, double-blind, parallel-group trial. Arthritis Rheum. 2008, 59, 1540-1548. [CrossRef] [PubMed]

36. Becker, M.A.; Schumacher, H.R.; Espinoza, L.R.; Wells, A.F.; MacDonald, P.; Lloyd, E.; Lademacher, C. The urate-lowering efficacy and safety of febuxostat in the treatment of the hyperuricemia of gout: The CONFIRMS trial. Arthritis Res. Ther. 2010, 12, R63. [CrossRef] [PubMed]

37. Yamaguchi, A.; Harada, M.; Yamada, Y.; Hashimoto, K.; Kamijo, Y. Identification of chronic kidney disease patient characteristics influencing the renoprotective effects of febuxostat therapy: A retrospective follow-up study. BMC Nephrol. 2017, 18, 162. [CrossRef] [PubMed] 
38. Sindhu, R.K.; Ehdaie, A.; Farmand, F.; Dhaliwal, K.K.; Nguyen, T.; Zhan, C.D.; Roberts, C.K.; Vaziri, N.D. Expression of catalase and glutathione peroxidase in renal insufficiency. Biochim. Biophys. Acta 2005, 1743, 86-92. [CrossRef] [PubMed]

39. Ross, E.A.; Koo, L.C.; Moberly, J.B. Low whole blood and erythrocyte levels of glutathione in hemodialysis and peritoneal dialysis patients. Am. J. Kidney Dis. 1997, 30, 489-494. [CrossRef]

40. Ceballos-Picot, I.; Witko-Sarsat, V.; Merad-Boudia, M.; Nguyen, A.T.; Thévenin, M.; Jaudon, M.C.; Zingraff, J.; Verger, C.; Jungers, P.; Descamps-Latscha, B. Glutathione antioxidant system as a marker of oxidative stress in chronic renal failure. Free Radic Biol. Med. 1996, 21, 845-853. [CrossRef]

41. Tbahriti, H.F.; Kaddous, A.; Bouchenak, M.; Mekki, K. Effect of different stages of chronic kidney disease and renal replacement therapies on oxidant-antioxidant balance in uremic patients. Biochem. Res. Int. 2013, 2013, 358985. [CrossRef] [PubMed]

42. Granata, S.; Dalla Gassa, A.; Tomei, P.; Lupo, A.; Zaza, G. Mitochondria: A new therapeutic target in chronic kidney disease. Nutr. Metab. 2015, 12, 49. [CrossRef] [PubMed]

43. Guarnieri, G.; Situlin, R.; Biolo, G. Carnitine metabolism in uremia. Am. J. Kidney Dis. 2001, 38, S63-S67. [CrossRef] [PubMed]

44. Sharma, S.; Black, S.M. Carnitine homeostasis, mitochondrial function, and cardiovascular disease. Drug Discov. Today Dis. Mech. 2009, 6, e31-e39. [CrossRef] [PubMed]

45. Kerner, J.; Hoppel, C. Fatty acid import into mitochondria. Biochim. Biophys. Acta 2000, 1486, 1-17. [CrossRef]

46. Flanagan, J.L.; Simmons, P.A.; Vehige, J.; Willcox, M.D.; Garrett, Q. Role of carnitine in disease. Nutr. Metab. 2010, 7, 30. [CrossRef] [PubMed]

47. Gülçin, I. Antioxidant and antiradical activities of L-carnitine. Life Sci. 2006, 78, 803-811. [CrossRef] [PubMed]

48. Calò, L.A.; Pagnin, E.; Davis, P.A.; Semplicini, A.; Nicolai, R.; Calvani, M.; Pessina, A.C. Antioxidant effect of L-carnitine and its short chain esters: Relevance for the protection from oxidative stress related cardiovascular damage. Int. J. Cardiol. 2006, 107, 54-60. [CrossRef] [PubMed]

49. Arockia Rani, P.J.; Panneerselvam, C. Carnitine as a free radical scavenger in aging. Exp. Gerontol. 2001, 36, 1713-1726. [CrossRef]

50. Rani, P.J.; Panneerselvam, C. Effect of L-carnitine on brain lipid peroxidation and antioxidant enzymes in old rats. J. Gerontol. A Biol. Sci. Med. Sci. 2002, 57, B134-B137. [CrossRef] [PubMed]

51. Guarnieri, G. Carnitine in maintenance hemodialysis patients. J. Ren. Nutr. 2015, 25, 169-175. [CrossRef] [PubMed]

52. Di Liberato, L.; Arduini, A.; Rossi, C.; Di Castelnuovo, A.; Posari, C.; Sacchetta, P.; Urbani, A.; Bonomini, M. L-Carnitine status in end-stage renal disease patients on automated peritoneal dialysis. J. Nephrol. 2014, 27, 699-706. [CrossRef] [PubMed]

53. Fatouros, I.G.; Douroudos, I.; Panagoutsos, S.; Pasadakis, P.; Nikolaidis, M.G.; Chatzinikolaou, A.; Sovatzidis, A.; Michailidis, Y.; Jamurtas, A.Z.; Mandalidis, D.; et al. Effects of L-carnitine on oxidative stress responses in patients with renal disease. Med. Sci. Sports Exerc. 2010, 42, 1809-1818. [CrossRef] [PubMed]

54. Pertosa, G.; Grandaliano, G.; Simone, S.; Soccio, M.; Schena, F.P. Inflammation and carnitine in hemodialysis patients. J. Ren. Nutr. 2005, 15, 8-12. [CrossRef] [PubMed]

55. Golper, T.A.; Goral, S.; Becker, B.N.; Langman, C.B. L-carnitine treatment of anemia. Am. J. Kidney Dis. 2003, 41, S27-S34. [CrossRef]

56. Kletzmayr, J.; Mayer, G.; Legenstein, E.; Heinz-Peer, G.; Leitha, T.; Hörl, W.H.; Kovarik, J. Anemia and carnitine supplementation in hemodialyzed patients. Kidney Int. Suppl. 1999, 69, S93-S106. [CrossRef] [PubMed]

57. Yee, J. L-carnitine for anemia in hemodialysis patients: A last resort. Clin. J. Am. Soc. Nephrol. 2012, 7, 1746-1748. [CrossRef] [PubMed]

58. Hurot, J.M.; Cucherat, M.; Haugh, M.; Fouque, D. Effects of L-carnitine supplementation in maintenance hemodialysis patients: A systematic review. J. Am. Soc. Nephrol. 2002, 13, 708-714. [PubMed]

59. Mercadal, L.; Coudert, M.; Vassault, A.; Pieroni, L.; Debure, A.; Ouziala, M.; Depreneuf, H.; Fumeron, C.; Servais, A.; Bassilios, N.; et al. L-carnitine treatment in incident hemodialysis patients: The multicenter, randomized, double-blinded, placebo-controlled CARNIDIAL trial. Clin. J. Am. Soc. Nephrol. 2012, 7, 1836-1842. [CrossRef] [PubMed]

60. Eknoyan, G.; Latos, D.L.; Lindberg, J.; National Kidney Foundation Carnitine Consensus Conference. Practice recommendations for the use of L-carnitine in dialysis-related carnitine disorder. National Kidney Foundation Carnitine Consensus Conference. Am. J. Kidney Dis. 2003, 41, 868-876. [CrossRef] 
61. Kliger, A.S.; Foley, R.N.; Goldfarb, D.S.; Goldstein, S.L.; Johansen, K.; Singh, A.; Szczech, L. KDOQI US commentary on the 2012 KDIGO Clinical Practice Guideline for Anemia in CKD. Am. J. Kidney Dis. 2013, 62, 849-859. [CrossRef] [PubMed]

62. Chen, Y.; Abbate, M.; Tang, L.; Cai, G.; Gong, Z.; Wei, R.; Zhou, J.; Chen, X. L-Carnitine supplementation for adults with end-stage kidney disease requiring maintenance hemodialysis: A systematic review and meta-analysis. Am. J. Clin. Nutr. 2014, 99, 408-422. [CrossRef] [PubMed]

63. Yang, S.K.; Xiao, L.; Song, P.A.; Xu, X.; Liu, F.Y.; Sun, L. Effect of L-carnitine therapy on patients in maintenance hemodialysis: A systematic review and meta-analysis. J. Nephrol. 2014, 27, 317-329. [CrossRef] [PubMed]

64. IUPAC-IUB Joint Commission on Biochemical Nomenclature (JCBN). Nomenclature of tocopherols and related compounds. Recommendations 1981. Eur. J. Biochem. 1982, 123, 473-475.

65. Brigelius-Flohe, R.; Traber, M.G. Vitamin E: Function and metabolism. FASEB J. 1999, 13, 1145-1155. [PubMed]

66. Traber, M.G.; Atkinson, J. Vitamin E antioxidant and nothing more. Free Radic. Biol. Med. 2007, 43, 4-15. [CrossRef] [PubMed]

67. Serbinova, E.; Kagan, V.; Han, D.; Packer, L. Free radical recycling and intramembrane mobility in the antioxidant properties of $\alpha$-tocopherol and $\alpha$-tocotrienol. Free Radic. Biol. Med. 1991, 10, 263-275. [CrossRef]

68. Princen, H.M.; van Duyvenvoorde, W.; Buytenhek, R.; van der Laarse, A.; van Poppel, G.; Gevers Leuven, J.A.; van Hinsbergh, V.W. Supplementation with low doses of vitamin E protects LDL from lipid peroxidation in men and women. Arterioscler. Thromb. Vasc. Biol. 1995, 15, 325-333. [CrossRef] [PubMed]

69. Cachia, O.; Benna, J.E.; Pedruzzi, E.; Descomps, B.; Gougerot-Pocidalo, M.A.; Leger, C.L. $\alpha$-tocopherol inhibits the respiratory burst in human monocytes. Attenuation of $\mathrm{p} 47$ (phox) membrane translocation and phosphorylation. J. Biol. Chem. 1998, 273, 32801-32805. [CrossRef] [PubMed]

70. Bozaykut, P.; Karademir, B.; Yazgan, B.; Sozen, E.; Siow, R.C.; Mann, G.E.; Ozer, N.K. Effects of vitamin E on peroxisome proliferator-activated receptor $\gamma$ and nuclear factor-erythroid 2-related factor 2 in hypercholesterolemia-induced atherosclerosis. Free Radic. Biol. Med. 2014, 70, 174-181. [CrossRef] [PubMed]

71. Stephens, N.G.; Parsons, A.; Schofield, P.M.; Kelly, F.; Cheeseman, K.; Mitchinson, M.J. Randomised controlled trial of vitamin $\mathrm{E}$ in patients with coronary disease: Cambridge Heart Antioxidant Study (CHAOS). Lancet 1996, 347, 781-786. [CrossRef]

72. Traber, M.G.; Stevens, J.F. Vitamins C and E: Beneficial effects from a mechanistic perspective. Free Radic. Biol. Med. 2011, 51, 1000-1013. [CrossRef] [PubMed]

73. Yoshikawa, T.; Yoshida, N.; Manabe, H.; Terasawa, Y.; Takemura, T.; Kondo, M. $\alpha$-Tocopherol protects against expression of adhesion molecules on neutrophils and endothelial cells. Biofactors 1998, 7, 15-19. [CrossRef] [PubMed]

74. Villacorta, L.; Graça-Souza, A.V.; Ricciarelli, R.; Zingg, J.M.; Azzi, A. $\alpha$-Tocopherol induces expression of connective tissue growth factor and antagonizes tumor necrosis factor- $\alpha$-mediated downregulation in human smooth muscle cells. Circ. Res. 2003, 92, 104-110. [CrossRef] [PubMed]

75. Azzi, A.; Gysin, R.; Kempná, P.; Munteanu, A.; Negis, Y.; Villacorta, L.; Visarius, T.; Zingg, J.M. Vitamin E mediates cell signaling and regulation of gene expression. Ann. N. Y. Acad. Sci. 2004, 1031, 86-95. [CrossRef] [PubMed]

76. Kuemerle, N.B.; Brandt, R.B.; Chan, W.; Krieg, R.J., Jr.; Chan, J.C. Inhibition of transforming growth factor ß-1 induction by dietary vitamin E in unilateral obstruction in rats. Biochem. Mol. Med. 1997, 61, 82-96. [CrossRef]

77. Boaz, M.; Smetana, S.; Weinstein, T.; Matas, Z.; Gafter, U.; Iaina, A.; Knecht, A.; Weissgarten, Y.; Brunner, D.; Fainaru, M.; et al. Secondary prevention with antioxidants of cardiovascular disease in end stage renal disease (SPACE): Randomised placebo-controlled trial. Lancet 2000, 356, 1213-1218. [CrossRef]

78. Mann, J.F.; Lonn, E.M.; Yi, Q.; Gerstein, H.C.; Hoogwerf, B.J.; Pogue, J.; Bosch, J.; Dagenais, G.R.; Yusuf, S.; HOPE Investigators. Effects of vitamin $\mathrm{E}$ on cardiovascular outcomes in people with mild to moderate renal insufficiency: Results of the HOPE study. Kidney Int. 2004, 65, 1375-1380. [CrossRef] [PubMed]

79. Tasanarong, A.; Vohakiat, A.; Hutayanon, P.; Piyayotai, D. New strategy of $\alpha$ - and $\gamma$-tocopherol to prevent contrast-induced acute kidney injury in chronic kidney disease patients undergoing elective coronary procedures. Nephrol. Dial. Transplant. 2013, 28, 337-344. [CrossRef] [PubMed]

80. Rezaei, Y.; Khademvatani, K.; Rahimi, B.; Khoshfetrat, M.; Arjmand, N.; Seyyed-Mohammadzad, M.H. Short-Term High-Dose Vitamin E to Prevent Contrast Medium-Induced Acute Kidney Injury in Patients With Chronic Kidney Disease Undergoing Elective Coronary Angiography: A Randomized Placebo-Controlled Trial. J. Am. Heart. Assoc. 2016, 5, e002919. [CrossRef] [PubMed] 
81. Yang, C.C.; Hsu, S.P.; Wu, M.S.; Hsu, S.M.; Chien, C.T. Effects of vitamin C infusion and vitamin E-coated membrane on hemodialysis-induced oxidative stress. Kidney Int. 2006, 69, 706-714. [CrossRef] [PubMed]

82. Takouli, L.; Hadjiyannakos, D.; Metaxaki, P.; Sideris, V.; Filiopoulos, V.; Anogiati, A.; Vlassopoulos, D. Vitamin E-coated cellulose acetate dialysis membrane: Long-term effect on inflammation and oxidative stress. Ren. Fail. 2010, 32, 287-293. [CrossRef] [PubMed]

83. Kirmizis, D.; Papagianni, A.; Belechri, A.M.; Memmos, D. Effects of vitamin E-coated membrane dialyser on markers of oxidative stress and inflammation in patients on chronic haemodialysis. Nephrol. Dial. Transplant. 2011, 26, 2296-2301. [CrossRef] [PubMed]

84. Panichi, V.; Rosati, A.; Paoletti, S.; Ferrandello, P.; Migliori, M.; Beati, S.; Bernabini, G.; Daini, R.; Casani, A.; Angelini, D.; et al. A vitamin E-coated polysulfone membrane reduces serum levels of inflammatory markers and resistance to erythropoietin-stimulating agents in hemodialysis patients: Results of a randomized cross-over multicenter trial. Blood Purif. 2011, 32, 7-14. [CrossRef] [PubMed]

85. Kitamura, Y.; Kamimura, K.; Yoshioka, N.; Hosotani, Y.; Tsuchida, K.; Koremoto, M.; Minakuchi, J. The effect of vitamin E-bonded polysulfone membrane dialyzer on a new oxidative lipid marker. J. Artif. Organ. 2013, 16, 206-210. [CrossRef] [PubMed]

86. Lines, S.W.; Carter, A.M.; Dunn, E.J.; Lindley, E.J.; Tattersall, J.E.; Wright, M.J. A randomized controlled trial evaluating the erythropoiesis stimulating agent sparing potential of a vitamin E-bonded polysulfone dialysis membrane. Nephrol. Dial. Transplant. 2014, 29, 649-656. [CrossRef] [PubMed]

87. Yang, S.K.; Xiao, L.; Xu, B.; Xu, X.X.; Liu, F.Y.; Sun, L. Effects of vitamin E-coated dialyzer on oxidative stress and inflammation status in hemodialysis patients: A systematic review and meta-analysis. Ren. Fail. 2014, 36, 722-731. [CrossRef] [PubMed]

88. Veringa, S.J.; Nanayakkara, P.W.; van Ittersum, F.J.; Vegting, I.L.; van Guldener, C.; Smulders, Y.M.; ter Wee, P.M.; Stehouwer, C.D. Effect of a treatment strategy consisting of pravastatin, vitamin, E.; and homocysteine lowering on arterial compliance and distensibility in patients with mild to moderate chronic kidney disease. Clin. Nephrol. 2012, 78, 263-272. [CrossRef] [PubMed]

89. Nanayakkara, P.W.; van Guldener, C.; ter Wee, P.M.; Scheffer, P.G.; van Ittersum, F.J.; Twisk, J.W.; Teerlink, T.; van Dorp, W.; Stehouwer, C.D. Effect of a treatment strategy consisting of pravastatin, vitamin, E.; and homocysteine lowering on carotid intima-media thickness, endothelial function, and renal function in patients with mild to moderate chronic kidney disease: Results from the Antioxidant Therapy in Chronic Renal Insufficiency (ATIC) Study. Arch. Intern. Med. 2007, 167, 1262-1270. [PubMed]

90. Pearson, P.; Lewis, S.A.; Britton, J.; Young, I.S.; Fogarty, A. The pro-oxidant activity of high-dose vitamin E supplements in vivo. BioDrugs 2006, 20, 271-273. [CrossRef] [PubMed]

91. Antoniadi, G.; Eleftheriadis, T.; Liakopoulos, V.; Kakasi, E.; Kartsios, C.; Passadakis, P.; Vargemezis, V. Effect of one-year oral $\alpha$-tocopherol administration on the antioxidant defense system in hemodialysis patients. Ther. Apher. Dial. 2008, 12, 237-242. [CrossRef] [PubMed]

92. Kagan, V.E.; Serbinova, E.A.; Forte, T.; Scita, G.; Packer, L. Recycling of vitamin E in human low density lipoproteins. J. Lipid Res. 1992, 33, 385-397. [PubMed]

93. Sesso, H.D.; Buring, J.E.; Christen, W.G.; Kurth, T.; Belanger, C.; MacFadyen, J.; Bubes, V.; Manson, J.E.; Glynn, R.J.; Gaziano, J.M. Vitamins $\mathrm{E}$ and $\mathrm{C}$ in the prevention of cardiovascular disease in men: The Physicians' Health Study II randomized controlled trial. JAMA 2008, 300, 2123-2133. [CrossRef] [PubMed]

94. Clase, C.M.; Ki, V.; Holden, R.M. Water-soluble vitamins in people with low glomerular filtration rate or on dialysis: A review. Semin. Dial. 2013, 26, 546-567. [CrossRef] [PubMed]

95. Monsen, E.R. Dietary reference intakes for the antioxidant nutrients: Vitamin, C.; vitamin, E.; selenium, and carotenoids. J. Am. Diet Assoc. 2000, 100, 637-640. [CrossRef]

96. Descamps-Latscha, B.; Drüeke, T.; Witko-Sarsat, V. Dialysis-induced oxidative stress: Biological aspects, clinical consequences, and therapy. Semin. Dial. 2001, 14, 193-199. [CrossRef] [PubMed]

97. Gruss-Fischer, T.; Fabian, I. Protection by ascorbic acid from denaturation and release of cytochrome c, alteration of mitochondrial membrane potential and activation of multiple caspases induced by $\mathrm{H}_{2} \mathrm{O}_{2}$, in human leukemia cells. Biochem. Pharmacol. 2002, 63, 1325-1335. [CrossRef]

98. Perez-Cruz, I.; Carcamo, J.M.; Golde, D.W. Vitamin C inhibits FAS-induced apoptosis in monocytes and U937 cells. Blood 2003, 102, 336-343. [CrossRef] [PubMed]

99. Dhar-Mascareño, M.; Cárcamo, J.M.; Golde, D.W. Hypoxia-reoxygenation-induced mitochondrial damage and apoptosis in human endothelial cells are inhibited by vitamin C. Free Radic. Biol. Med. 2005, 38, 1311-1322. 
100. KC, S.; Cárcamo, J.M.; Golde, D.W. Vitamin C enters mitochondria via facilitative glucose transporter 1 (Glut1) and confers mitochondrial protection against oxidative injury. FASEB J. 2005, 19, 1657-1667. [CrossRef] [PubMed]

101. May, J.M.; Qu, Z.C.; Whitesell, R.R.; Cobb, C.E. Ascorbate recycling in human erythrocytes: Role of GSH in reducing dehydroascorbate. Free Radic Biol Med. 1996, 20, 543-551. [CrossRef]

102. Nguyen-Khoa, T.; Massy, Z.A.; De Bandt, J.P.; Kebede, M.; Salama, L.; Lambrey, G.; Witko-Sarsat, V.; Drüeke, T.B.; Lacour, B.; Thévenin, M. Oxidative stress and haemodialysis: Role of inflammation and duration of dialysis treatment. Nephrol. Dial. Transplant. 2001, 16, 335-3540. [CrossRef] [PubMed]

103. Deicher, R.; Horl, W.H. Vitamin C in chronic kidney disease and hemodialysis patients. Kidney Blood Press. Res. 2003, 26, 100-106. [CrossRef] [PubMed]

104. Deicher, R.; Ziai, F.; Bieglmayer, C.; Schillinger, M.; Hörl, W.H. Low total vitamin C plasma level is a risk factor for cardiovascular morbidity and mortality in hemodialysis patients. J. Am. Soc. Nephrol. 2005, 16, 1811-1818. [CrossRef] [PubMed]

105. Takahashi, N.; Morimoto, S.; Okigaki, M.; Seo, M.; Someya, K.; Morita, T.; Matsubara, H.; Sugiura, T.; Iwasaka, T. Decreased plasma level of vitamin C in chronic kidney disease: Comparison between diabetic and non-diabetic patients. Nephrol. Dial. Transplant. 2011, 26, 1252-1257. [CrossRef] [PubMed]

106. Kamgar, M.; Zaldivar, F.; Vaziri, N.D.; Pahl, M.V. Antioxidant therapy does not ameliorate oxidative stress and inflammation in patients with end-stage renal disease. J. Natl. Med. Assoc. 2009, 101, 336-344. [CrossRef]

107. Singer, R.F. Vitamin C supplementation in kidney failure: Effect on uraemic symptoms. Nephrol. Dial. Transplant. 2011, 26, 614-620. [CrossRef] [PubMed]

108. Zhang, K.; Li, Y.; Cheng, X.; Liu, L.; Bai, W.; Guo, W.; Wu, L.; Zuo, L. Cross-over study of influence of oral vitamin $\mathrm{C}$ supplementation on inflammatory status in maintenance hemodialysis patients. BMC Nephrol. 2013, 14, 252. [CrossRef] [PubMed]

109. Deved, V.; Poyah, P.; James, M.T.; Tonelli, M.; Manns, B.J.; Walsh, M.; Hemmelgarn, B.R. Alberta Kidney Disease Network. Ascorbic acid for anemia management in hemodialysis patients: A systematic review and meta-analysis. Am. J. Kidney Dis. 2009, 54, 1089-1097. [CrossRef] [PubMed]

110. Kang, D.W.; Ahn, C.Y.; Ryu, B.K.; Shin, B.C.; Chung, J.H.; Kim, H.L. The effect of intravenous ascorbic acid in hemodialysis patients with normoferritinemic anemia. Kidney Res. Clin. Pract. 2012, 31, 48-53. [CrossRef] [PubMed]

111. Ernster, L.; Dallner, G. Biochemical, physiological and medical aspects of ubiquinone function. Biochim. Biophys. Acta 1995, 1271, 195-204. [CrossRef]

112. Pravst, I.; Zmitek, K.; Zmitek, J. Coenzyme Q10 contents in foods and fortification strategies. Crit. Rev. Food Sci. Nutr. 2010, 50, 269-280. [CrossRef] [PubMed]

113. Bentinger, M.; Tekle, M.; Dallner, G. Coenzyme Q-Biosynthesis and functions. Biochem. Biophys. Res. Commun. 2010, 396, 74-79. [CrossRef] [PubMed]

114. Bentinger, M.; Brismar, K.; Dallner, G. The antioxidant role of coenzyme Q. Mitochondrion 2007, 7, S41-S50. [CrossRef] [PubMed]

115. Papucci, L.; Schiavone, N.; Witort, E.; Donnini, M.; Lapucci, A.; Tempestini, A.; Formigli, L.; Zecchi-Orlandini, S.; Orlandini, G.; et al. Coenzyme q10 prevents apoptosis by inhibiting mitochondrial depolarization independently of its free radical scavenging property. J. Biol. Chem. 2003, 278, 28220-28228. [CrossRef] [PubMed]

116. Bergamini, C.; Moruzzi, N.; Sblendido, A.; Lenaz, G.; Fato, R. A water soluble CoQ10 formulation improves intracellular distribution and promotes mitochondrial respiration in cultured cells. PLoS ONE 2012, 7, e33712. [CrossRef] [PubMed]

117. Gazdíková, K.; Gvozdjáková, A.; Kucharská, J.; Spustová, V.; Braunová, Z.; Dzúrik, R. Oxidative stress and plasma concentrations of coenzyme Q10, $\alpha$-tocopherol, and beta-carotene in patients with a mild to moderate decrease of kidney function. Nephron 2001, 88, 285. [CrossRef] [PubMed]

118. Lippa, S.; Colacicco, L.; Callà, C.; Sagliaschi, G.; Angelitti, A.G. Coenzyme Q10 levels, plasma lipids and peroxidation extent in renal failure and in hemodialytic patients. Mol. Aspects Med. 1994, 15, S213-S219. [CrossRef]

119. Macunluoglu, B.; Atakan, A.; Ari, E.; Kaya, Y.; Kaspar, C.; Demir, H.; Alp, H.H. Epicardial fat tissue thickness is correlated with diminished levels of co-enzyme Q10, a major antioxidant molecule among hemodialysis patients. Clin. Biochem. 2014, 47, 1231-1234. [CrossRef] [PubMed] 
120. Mazurek, T.; Zhang, L.; Zalewski, A.; Mannion, J.D.; Diehl, J.T.; Arafat, H.; Sarov-Blat, L.; O’Brien, S.; Keiper, E.A.; Johnson, A.G.; et al. Human epicardial adipose tissue is a source of inflammatory mediators. Circulation 2003, 108, 2460-2466. [CrossRef] [PubMed]

121. Baker, A.R.; Silva, N.F.; Quinn, D.W.; Harte, A.L.; Pagano, D.; Bonser, R.S.; Kumar, S.; McTernan, P.G. Human epicardial adipose tissue expresses a pathogenic profile of adipocytokines in patients with cardiovascular disease. Cardiovasc. Diabetol. 2006, 5, 1. [CrossRef] [PubMed]

122. Sacks, H.S.; Fain, J.N. Human epicardial adipose tissue: A review. Am. Heart J. 2007, 153, 907-917. [CrossRef] [PubMed]

123. Turkmen, K.; Ozbek, O.; Kayikcioğlu, H.; Kayrak, M.; Solak, Y.; Nayman, A.; Anil, M.; Babur, H.; Tonbul, H.Z. The Relationship between Epicardial Adipose Tissue and Coronary Artery Calcification in Peritoneal Dialysis Patients. Cardiorenal. Med. 2012, 2, 43-51. [CrossRef] [PubMed]

124. Atakan, A.; Macunluoglu, B.; Kaya, Y.; Ari, E.; Demir, H.; Asicioglu, E.; Kaspar, C. Epicardial fat thickness is associated with impaired coronary flow reserve in hemodialysis patients. Hemodial. Int. 2014, 18, 62-69. [CrossRef] [PubMed]

125. Gokbel, H.; Turk, S.; Okudan, N.; Atalay, H.; Belviranli, M.; Gaipov, A.; Solak, Y. Effects of Coenzyme Q10 Supplementation on Exercise Performance and Markers of Oxidative Stress in Hemodialysis Patients: A Double-Blind Placebo-Controlled Crossover Trial. Am. J. Ther. 2016, 23, e1736-e1743. [CrossRef] [PubMed]

126. Reed, L.J.; debusk, B.G.; Gunsalus, I.; Hornberger, C., Jr. Crystalline $\alpha$-lipoic acid; A catalytic agent associated with pyruvate dehydrogenase. Science 1951, 114, 93-94. [CrossRef] [PubMed]

127. Shay, K.P.; Moreau, R.F.; Smith, E.J.; Smith, A.R.; Hagen, T.M. $\alpha$-lipoic acid as a dietary supplement: Molecular mechanisms and therapeutic potential. Biochim. Biophys. Acta 2009, 1790, 1149-1160. [CrossRef] [PubMed]

128. Sigel, H.; Prijs, B.; McCormick, D.B.; Shih, J.C. Stability of binary and ternary complexes of a-lipoate and lipoate derivatives with $\mathrm{Mn}^{2+}, \mathrm{Cu}^{2+}$, and $\mathrm{Zn}^{2+}$ in solution. Arch. Biochem. Biophys. 1978, 187, 208-214. [CrossRef]

129. Liu, J. The effects and mechanisms of mitochondrial nutrient $\alpha$-lipoic acid on improving age-associated mitochondrial and cognitive dysfunction: An overview. Neurochem. Res. 2008, 33, 194-203. [CrossRef] [PubMed]

130. Packer, L. $\alpha$-Lipoic acid: A metabolic antioxidant which regulates NF- $\mathrm{kB}$ signal transduction and protects against oxidative injury. Drug Metab. Rev. 1998, 30, 245-275. [CrossRef] [PubMed]

131. Petersen Shay, K.; Moreau, R.F.; Smith, E.J.; Hagen, T.M. Is $\alpha$-lipoic acid a scavenger of reactive oxygen species in vivo? Evidence for its initiation of stress signaling pathways that promote endogenous antioxidant capacity. IUBMB Life 2008, 60, 362-367. [CrossRef] [PubMed]

132. Kim, H.; Kim, H.J.; Lee, K.; Kim, J.M.; Kim, H.S.; Kim, J.R.; Ha, C.M.; Choi, Y.K.; Lee, S.J.; Kim, J.Y.; Harris, R.A.; Jeong, D.; Lee, I.K. $\alpha$-Lipoic acid attenuates vascular calcification via reversal of mitochondrial function and restoration of Gas6/Axl/Akt survival pathway. J. Cell. Mol. Med. 2012, 16, 273-286. [CrossRef] [PubMed]

133. Wang, L.; Wu, C.G.; Fang, C.Q.; Gao, J.; Liu, Y.Z.; Chen, Y.; Chen, Y.N.; Xu, Z.G. The protective effect of $\alpha$-Lipoic acid on mitochondria in the kidney of diabetic rats. Int. J. Clin. Exp. Med. 2013, 6, 90-97. [PubMed]

134. Melhem, M.F.; Craven, P.A.; Liachenko, J.; De Rubertis, F.R. $\alpha$-lipoic acid attenuates hyperglycemia and prevents glomerular mesangial matrix expansion in diabetes. J. Am. Soc. Nephrol. 2002, 13, 16.

135. Khabbazi, T.; Mahdavi, R.; Safa, J.; Pour-Abdollahi, P. Effects of $\alpha$-lipoic acid supplementation on inflammation, oxidative stress, and serum lipid profile levels in patients with end-stage renal disease on hemodialysis. J. Ren. Nutr. 2012, 22, 244-250. [CrossRef] [PubMed]

136. Chang, J.W.; Lee, E.K.; Kim, T.H.; Min, W.K.; Chun, S.; Lee, K.U.; Kim, S.B.; Park, J.S. Effects of $\alpha$ lipoic acid on the plasma levels of asymmetric dimethylarginine in diabetic end-stage renal disease patients on hemodialysis: A pilot study. Am. J. Nephrol. 2007, 27, 70-74. [CrossRef] [PubMed]

137. Safa, J.; Ardalan, M.R.; Rezazadehsaatlou, M.; Mesgari, M.; Mahdavi, R.; Jadid, M.P. Effects of $\alpha$ lipoic acid supplementation on serum levels of IL-8 and TNF- $\alpha$ in patient with ESRD undergoing hemodialysis. Int. Urol. Nephrol. 2014, 46, 1633-1638. [CrossRef] [PubMed]

138. Ramos, L.F.; Kane, J.; McMonagle, E.; Le, P.; Wu, P.; Shintani, A. Effects of combination tocopherols and $\alpha$ lipoic acid therapy on oxidative stress and inflammatory biomarkers in chronic kidney disease. J. Ren. Nutr. 2011, 21, 211-218. [CrossRef] [PubMed] 
139. Himmelfarb, J.; Ikizler, T.A.; Ellis, C.; Wu, P.; Shintani, A.; Dalal, S.; Kaplan, M.; Chonchol, M.; Hakim, R.M. Provision of antioxidant therapy in hemodialysis (PATH): A randomized clinical trial. J. Am. Soc. Nephrol. 2014, 25, 623-633. [CrossRef]

140. Tinggi, U. Selenium: Its role as antioxidant in human health. Environ. Health Prev. Med. 2008, 13, $102-108$. [CrossRef]

141. Rayman, M.P. Selenium and human health. Lancet 2012, 379, 1256. [CrossRef]

142. Fujishima, Y.; Ohsawa, M.; Itai, K.; Kato, K.; Tanno, K.; Turin, T.C.; Onoda, T.; Endo, S.; Okayama, A.; Fujioka, T. Serum selenium levels are inversely associated with death risk among hemodialysis patients. Nephrol. Dial. Transplant. 2011, 26, 3331-3338. [CrossRef] [PubMed]

143. Rucker, D.; Thadhani, R.; Tonelli, M. Trace element status in hemodialysis patients. Semin. Dial. 2010, 23, 389-395. [CrossRef] [PubMed]

144. Tonelli, M.; Wiebe, N.; Hemmelgarn, B.; Klarenbach, S.; Field, C.; Manns, B.; Thadhani, R.; Gill, J. Alberta Kidney Disease Network. Trace elements in hemodialysis patients: A systematic review and meta-analysis. BMC Med. 2009, 7, 25. [CrossRef] [PubMed]

145. Pakfetrat, M.; Malekmakan, L.; Hasheminasab, M. Diminished selenium levels in hemodialysis and continuous ambulatory peritoneal dialysis patients. Biol. Trace Elem. Res. 2010, 137, 335-339. [CrossRef] [PubMed]

146. Sedighi, O.; Zargari, M.; Varshi, G. Effect of selenium supplementation on glutathione peroxidase enzyme activity in patients with chronic kidney disease: A randomized clinical trial. Nephrourol. Mon. 2014, 6, e17945. [CrossRef] [PubMed]

147. Zachara, B.A.; Koterska, D.; Manitius, J.; Sadowski, L.; Dziedziczko, A.; Salak, A.; Wasowicz, W. Selenium supplementation on plasma glutathione peroxidase activity in patients with end-stage chronic renal failure. Biol. Trace Elem Res. 2004, 97, 15-30. [CrossRef]

148. Zachara, B.A.; Gromadzinska, J.; Palus, J.; Zbrog, Z.; Swiech, R.; Twardowska, E.; Wasowicz, W. The effect of selenium supplementation in the prevention of DNA damage in white blood cells of hemodialyzed patients: A pilot study. Biol. Trace Elem. Res. 2011, 142, 274-283. [CrossRef] [PubMed]

149. Salehi, M.; Sohrabi, Z.; Ekramzadeh, M.; Fallahzadeh, M.K.; Ayatollahi, M.; Geramizadeh, B.; Hassanzadeh, J.; Sagheb, M.M. Selenium supplementation improves the nutritional status of hemodialysis patients: A randomized, double-blind, placebo-controlled trial. Nephrol. Dial. Transplant. 2013, 28, 716-723. [CrossRef] [PubMed]

150. Omrani, H.R.; Rahimi, M.; Nikseresht, K. The effect of selenium supplementation on acute phase reactants and thyroid function tests in hemodialysis patients. Nephrourol. Mon. 2015, 7, e24781. [CrossRef] [PubMed]

151. Ardalan, M.R.; Tubbs, R.S.; Shoja, M.M. Vitamin E and selenium co-supplementation attenuates oxidative stress in haemodialysis patients receiving intra-dialysis iron infusion. Nephrol. Dial. Transplant. 2007, 22, 973-975. [CrossRef] [PubMed]

152. Baptista, J.A.B.; Tavares, J.F.D.; Carvalho, R.C.B. Comparison of catechins and aromas among different green teas using HPLC/SPME-GC. Food Res. Int. 1998, 31, 729-736. [CrossRef]

153. Yokozawa, T.; Dong, E.; Nakagawa Kashiwagi, H.; Nakagawa, H.; Takeuchi, S.; Chung, H.Y. In vitro and in vivo studies on the radical-scavenging activity of tea. J. Agric. Food Chem. 1998, 46, 2143-2150. [CrossRef]

154. Nanjo, F.; Mori, M.; Goto, K.; Hara, Y. Radical scavenging activity of tea catechins and their related compounds. Biosci. Biotechnol. Biochem. 1999, 63, 1621-1623. [CrossRef] [PubMed]

155. Zhao, B.; Guo, Q.; Xin, W. Free radical scavenging by green tea polyphenols. Methods Enzymolol. 2001, 335, 217-231.

156. Higdon, J.V.; Frei, B. Tea catechins and polyphenols: Health effects, metabolism, and antioxidant functions. Crit. Rev. Food Sci. Nutr. 2003, 43, 89-143. [CrossRef] [PubMed]

157. Bao, H.; Peng, A. The Green Tea Polyphenol(-)-epigallocatechin-3-gallate and its beneficial roles in chronic kidney disease. J. Transl. Int. Med. 2016, 4, 99-103. [CrossRef] [PubMed]

158. Peng, A.; Ye, T.; Rakheja, D.; Tu, Y.; Wang, T.; Du, Y.; Zhou, J.K.; Vaziri, N.D.; Hu, Z.; Mohan, C.; Zhou, X.J. The green tea polyphenol (-)-epigallocatechin-3-gallate ameliorates experimental immune-mediated glomerulonephritis. Kidney Int. 2011, 80, 601-611. [CrossRef] [PubMed]

159. Ye, T.; Zhen, J.; Du, Y.; Zhou, J.K.; Peng, A.; Vaziri, N.D.; Mohan, C.; Xu, Y.; Zhou, X.J. Green tea polyphenol (-)-epigallocatechin-3-gallate restores $\mathrm{Nrf} 2$ activity and ameliorates crescentic glomerulonephritis. PLoS ONE 2015, 10, e0119543. [CrossRef] [PubMed] 
160. Tsai, P.Y.; Ka, S.M.; Chang, J.M.; Chen, H.C.; Shui, H.A.; Li, C.Y.; Hua, K.F.; Chang, W.L.; Huang, J.J.; Yang, S.S.; et al. Epigallocatechin-3-gallate prevents lupus nephritis development in mice via enhancing the Nrf2 antioxidant pathway and inhibiting NLRP3 inflammasome activation. Free Radic. Biol. Med. 2011, 51, 744-754. [CrossRef] [PubMed]

161. Yamabe, N.; Yokozawa, T.; Oya, T.; Kim, M. Therapeutic potential of (-)-epigallocatechin 3-O-gallate on renal damage in diabetic nephropathy model rats. J. Pharmacol. Exp. Ther. 2006, 319, 228-236. [CrossRef] [PubMed]

162. Zhou, P.; Yu, J.F.; Zhao, C.G.; Sui, F.X.; Teng, X.; Wu, Y.B. Therapeutic potential of EGCG on acute renal damage in a rat model of obstructive nephropathy. Mol. Med. Rep. 2013, 7, 1096-1102. [PubMed]

163. Nakagawa, T.; Yokozawa, T.; Sano, M.; Takeuchi, S.; Kim, M.; Minamoto, S. Activity of (-)-epigallocatechin 3-O-gallate against oxidative stress in rats with adenine-induced renal failure. J. Agric. Food Chem. 2004, 52, 2103-2107. [CrossRef] [PubMed]

164. Kakuta, Y.; Okumi, M.; Isaka, Y.; Tsutahara, K.; Abe, T.; Yazawa, K.; Ichimaru, N.; Matsumura, K.; Hyon, S.H.; Takahara, S.; Nonomura, N. Epigallocatechin-3-gallate protects kidneys from ischemia reperfusion injury by HO-1 upregulation and inhibition of macrophage infiltration. Transpl. Int. 2011, 24, 514-522. [CrossRef] [PubMed]

165. Bertelli, A.A.; Das, D.K. Grapes, wines, resveratrol, and heart health. J. Cardiovasc. Pharmacol. 2009, 54, 468-476. [CrossRef] [PubMed]

166. Leonard, S.S.; Xia, C.; Jiang, B.H.; Stinefelt, B.; Klandorf, H.; Harris, G.K.; Shi, X. Resveratrol scavenges reactive oxygen species and effects radical-induced cellular responses. Biochem. Biophys. Res. Commun. 2003, 309, 1017-1026. [CrossRef] [PubMed]

167. Spanier, G.; Xu, H.; Xia, N.; Tobias, S.; Deng, S.; Wojnowski, L.; Forstermann, U.; Li, H. Resveratrol reduces endothelial oxidative stress by modulating the gene expression of superoxide dismutase 1 (SOD1), glutathione peroxidase 1 (GPx1) and NADPH oxidase subunit (Nox4). J. Physiol. Pharmacol. 2009, 60, 111-116. [PubMed]

168. Hao, C.M.; Haase, V.H. Sirtuins and their relevance to the kidney. J. Am. Soc. Nephrol. 2010, 21, 1620-1627. [CrossRef] [PubMed]

169. Imai, S.; Guarente, L. NAD+ and sirtuins in aging and disease. Trends Cell Biol. 2014, 24, 464-471. [CrossRef] [PubMed]

170. Rodgers, J.T.; Lerin, C.; Haas, W.; Gygi, S.P.; Spiegelman, B.M.; Puigserver, P. Nutrient control of glucose homeostasis through a complex of PGC-1 $\alpha$ and SIRT1. Nature 2005, 434, 113-118. [CrossRef] [PubMed]

171. Walker, A.K.; Yang, F.; Jiang, K.; Ji, J.Y.; Watts, J.L.; Purushotham, A.; Boss, O.; Hirsch, M.L.; Ribich, S.; Smith, J.J.; et al. Conserved role of SIRT1 orthologs in fasting-dependent inhibition of the lipid/cholesterol regulator SREBP. Genes Dev. 2010, 24, 1403-1417. [CrossRef] [PubMed]

172. Kitada, M.; Kume, S.; Takeda-Watanabe, A.; Kanasaki, K.; Koya, D. Sirtuins and renal diseases: Relationship with aging and diabetic nephropathy. Clin. Sci. 2013, 124, 153-164. [CrossRef] [PubMed]

173. Kitada, M.; Koya, D. Renal protective effects of resveratrol. Oxid. Med. Cell. Longev. 2013, $2013,568093$. [CrossRef] [PubMed]

174. Sharma, S.; Anjaneyulu, M.; Kulkarni, S.K.; Chopra, K. Resveratrol, a polyphenolic phytoalexin, attenuates diabetic nephropathy in rats. Pharmacology 2006, 76, 69-75. [CrossRef] [PubMed]

175. Palsamy, P.; Subramanian, S. Resveratrol protects diabetic kidney by attenuating hyperglycemia-mediated oxidative stress and renal inflammatory cytokines via Nrf2-Keap1 signaling. Biochim. Biophys. Acta 2011, 1812, 719-731. [CrossRef] [PubMed]

176. Zhang, L.; Pang, S.; Deng, B.; Qian, L.; Chen, J.; Zou, J.; Zheng, J.; Yang, L.; Zhang, C.; Chen, X.; et al. High glucose induces renal mesangial cell proliferation and fibronectin expression through JNK/NF- $\mathrm{B} / \mathrm{NADPH}$ oxidase/ROS pathway, which is inhibited by resveratrol. Int. J. Biochem. Cell Biol. 2012, 44, 629-638. [CrossRef] [PubMed]

177. Huang, S.S.; Ding, D.F.; Chen, S.; Dong, C.L.; Ye, X.L.; Yuan, Y.G.; Feng, Y.M.; You, N.; Xu, J.R.; Miao, H.; et al. Resveratrol protects podocytes against apoptosis via stimulation of autophagy in a mouse model of diabetic nephropathy. Sci. Rep. 2017, 7, 45692. [CrossRef] [PubMed]

178. Li, J.; Qu, X.; Ricardo, S.D.; Bertram, J.F.; Nikolic-Paterson, D.J. Resveratrol inhibits renal fibrosis in the obstructed kidney: Potential role in deacetylation of Smad3. Am. J. Pathol. 2010, 177, 1065-1071. [CrossRef] [PubMed] 
179. Liang, J.; Tian, S.; Han, J.; Xiong, P. Resveratrol as a therapeutic agent for renal fibrosis induced by unilateral ureteral obstruction. Ren. Fail. 2014, 36, 285-291. [CrossRef] [PubMed]

180. He, T.; Guan, X.; Wang, S.; Xiao, T.; Yang, K.; Xu, X.; Wang, J.; Zhao, J. Resveratrol prevents high glucose-induced epithelial-mesenchymal transition in renal tubular epithelial cells by inhibiting NADPH oxidase/ROS/ERK pathway. Mol. Cell Endocrinol. 2015, 402, 13-20. [CrossRef] [PubMed]

181. Huang, X.Z.; Wen, D.; Zhang, M.; Xie, Q.; Ma, L.; Guan, Y.; Ren, Y.; Chen, J.; Hao, C.M. Sirt1 activation ameliorates renal fibrosis by inhibiting the TGF- $\beta$ /Smad3 pathway. J. Cell. Biochem. 2014, 115, 996-1005. [CrossRef] [PubMed]

182. Sun, L.J.; Sun, Y.N.; Chen, S.J.; Liu, S.; Jiang, G.R. Resveratrol attenuates skeletal muscle atrophy induced by chronic kidney disease via MuRF1 signaling pathway. Biochem. Biophys. Res. Commun. 2017, 487, 83-89. [CrossRef] [PubMed]

183. Um, J.H.; Park, S.J.; Kang, H.; Yang, S.; Foretz, M.; McBurney, M.W.; Kim, M.K.; Viollet, B.; Chung, J.H. AMP-activated protein kinase-deficient mice are resistant to the metabolic effects of resveratrol. Diabetes 2010, 59, 554-563. [CrossRef] [PubMed]

184. Yuan, Y.; Huang, S.; Wang, W.; Wang, Y.; Zhang, P.; Zhu, C. Activation of peroxisome proliferator-activated receptor- $\gamma$ coactivator $1 \alpha$ ameliorates mitochondrial dysfunction and protects podocytes from aldosterone-induced injury. Kidney Int. 2012, 82, 771-789. [CrossRef] [PubMed]

185. Do Amaral, C.L.; Francescato, H.D.; Coimbra, T.M.; Costa, R.S.; Darin, J.D.; Antunes, L.M.; Bianchi, M.L. Resveratrol attenuates cisplatin-induced nephrotoxicity in rats. Arch. Toxicol. 2008, 82, 363-370. [CrossRef] [PubMed]

186. Bertelli, A.A.; Migliori, M.; Panichi, V.; Origlia, N.; Filippi, C.; Das, D.K.; Giovannini, L. Resveratrol, a component of wine and grapes, in the prevention of kidney disease. Ann. N. Y. Acad. Sci. 2002, 957, 230-238. [CrossRef] [PubMed]

187. Chen, L.; Yang, S.; Zumbrun, E.E.; Guan, H.; Nagarkatti, P.S.; Nagarkatti, M. Resveratrol attenuates lipopolysaccharide-induced acute kidney injury by suppressing inflammation driven by macrophages. Mol. Nutr. Food Res. 2015, 59, 853-864. [CrossRef] [PubMed]

188. Smoliga, J.M.; Blanchard, O. Enhancing the delivery of resveratrol in humans: If low bioavailability is the problem, what is the solution? Molecules 2014, 19, 17154-17172. [CrossRef] [PubMed]

189. Trujillo, J.; Chirino, Y.I.; Molina-Jijón, E.; Andérica-Romero, A.C.; Tapia, E.; Pedraza-Chaverrí, J. Renoprotective effect of the antioxidant curcumin: Recent findings. Redox Biol. 2013, 1, 448-456. [CrossRef] [PubMed]

190. Singh, S. From exotic spice to modern drug? Cell 2007, 130, 765-768. [CrossRef] [PubMed]

191. Calabrese, V.; Bates, T.E.; Mancuso, C.; Cornelius, C.; Ventimiglia, B.; Cambria, M.T. Curcumin and the cellular stress response in free radical-related diseases. Mol. Nutr. Food Res. 2008, 52, 1062-1073. [CrossRef] [PubMed]

192. Aggarwal, B.B.; Harikumar, K.B. Potential therapeutic effects of curcumin, the anti-inflammatory agent, against neurodegenerative, cardiovascular, pulmonary, metabolic, autoimmune and neoplastic diseases. Int. J. Biochem. Cell Biol. 2009, 41, 40-59. [CrossRef] [PubMed]

193. Fujisawa, S.; Atsumi, T.; Ishihara, M.; Kadoma, Y. Cytotoxicity, ROS-generation activity and radical-scavenging activity of curcumin and related compounds. Anticancer Res. 2004, 24, 563-569. [PubMed]

194. Mun, S.H.; Joung, D.K.; Kim, Y.S.; Kang, O.H.; Kim, S.B.; Seo, Y.S.; Kim, Y.C.; Lee, D.S.; Shin, D.W.; Kweon, K.T.; Kwon, D.Y. Synergistic antibacterial effect of curcumin against methicillin-resistant Staphylococcus aureus. Phytomedicine 2013, 20, 714-718. [CrossRef] [PubMed]

195. Ak, T.; Gülçin, I. Antioxidant and radical scavenging properties of curcumin. Chem. Biol. Interact. 2008, 174, 27-37. [CrossRef] [PubMed]

196. Barzegar, A.; Moosavi-Movahedi, A.A. Intracellular ROS protection efficiency and free radical-scavenging activity of curcumin. PLoS ONE 2011, 6, e26012. [CrossRef] [PubMed]

197. Das, K.C.; Das, C.K. Curcumin (diferuloylmethane), a singlet oxygen ((1)O(2)) quencher. Biochem. Biophys. Res. Commun. 2002, 295, 62-66. [CrossRef]

198. Kim, J.E.; Kim, A.R.; Chung, H.Y.; Han, S.Y.; Kim, B.S.; Choi, J.S. In vitro peroxynitrite scavenging activity of diarylheptanoids from Curcuma longa. Phytother. Res. 2003, 17, 481-484. [CrossRef] [PubMed]

199. Aggarwal, B.B.; Sung, B. Pharmacological basis for the role of curcumin in chronic diseases: An age-old spice with modern targets. Trends Pharmacol. Sci. 2009, 30, 85-94. [CrossRef] [PubMed] 
200. Jeong, G.S.; Oh, G.S.; Pae, H.O.; Jeong, S.O.; Kim, Y.C.; Shin, M.K.; Seo, B.Y.; Han, S.Y.; Lee, H.S.; Jeong, J.G.; et al. Comparative effects of curcuminoids on endothelial heme oxygenase-1 expression: Ortho-methoxy groups are essential to enhance heme oxygenase activity and protection. Exp. Mol. Med. 2006, 38, 393-400. [CrossRef] [PubMed]

201. Ye, S.F.; Hou, Z.Q.; Zhong, L.M.; Zhang, Q.Q. Effect of curcumin on the induction of glutathione S-transferases and $\mathrm{NADP}(\mathrm{H})$ :quinone oxidoreductase and its possible mechanism of action. Yao Xue Xue Bao 2007, 42, 376-380. [PubMed]

202. Rushworth, S.A.; Ogborne, R.M.; Charalambos, C.A.; O'Connell, M.A. Role of protein kinase C delta in curcumin-induced antioxidant response element-mediated gene expression in human monocytes. Biochem. Biophys. Res. Commun. 2006, 341, 1007-1016. [CrossRef] [PubMed]

203. Sharma, S.; Kulkarni, S.K.; Chopra, K. Curcumin, the active principle of turmeric (Curcuma longa), ameliorates diabetic nephropathy in rats. Clin. Exp. Pharmacol. Physiol. 2006, 33, 940-945. [CrossRef] [PubMed]

204. Soetikno, V.; Watanabe, K.; Sari, F.R.; Harima, M.; Thandavarayan, R.A.; Veeraveedu, P.T.; Arozal, W.; Sukumaran, V.; Lakshmanan, A.P.; Arumugam, S.; Suzuki, K. Curcumin attenuates diabetic nephropathy by inhibiting PKC- $\alpha$ and PKC- $\beta 1$ activity in streptozotocin-induced type I diabetic rats. Mol. Nutr. Food Res. 2011, 55, 1655-1665. [CrossRef] [PubMed]

205. Soetikno, V.; Sari, F.R.; Veeraveedu, P.T.; Thandavarayan, R.A.; Harima, M.; Sukumaran, V.; Lakshmanan, A.P.; Suzuki, K.; Kawachi, H.; Watanabe, K. Curcumin ameliorates macrophage infiltration by inhibiting NF-kB activation and proinflammatory cytokines in streptozotocin induced-diabetic nephropathy. Nutr. Metab. 2011, 8, 35. [CrossRef] [PubMed]

206. Chiu, J.; Khan, Z.A.; Farhangkhoee, H.; Chakrabarti, S. Curcumin prevents diabetes-associated abnormalities in the kidneys by inhibiting p300 and nuclear factor-кB. Nutrition 2009, 25, 964-972. [CrossRef] [PubMed]

207. Lu, M.; Yin, N.; Liu, W.; Cui, X.; Chen, S.; Wang, E. Curcumin Ameliorates Diabetic Nephropathy by Suppressing NLRP3 Inflammasome Signaling. BioMed Res. Int. 2017, 2017, 1516985. [CrossRef] [PubMed]

208. Ghosh, S.S.; Massey, H.D.; Krieg, R.; Fazelbhoy, Z.A.; Ghosh, S.; Sica, D.A.; Fakhry, I.; Gehr, T.W. Curcumin ameliorates renal failure in 5/6 nephrectomized rats: Role of inflammation. Am. J. Physiol. Ren. Physiol. 2009, 296, F1146-F1157. [CrossRef] [PubMed]

209. Ghosh, S.S.; Gehr, T.W.; Ghosh, S. Curcumin and chronic kidney disease (CKD): Major mode of action through stimulating endogenous intestinal alkaline phosphatase. Molecules 2014, 19, 20139-20156. [CrossRef] [PubMed]

210. Jacob, A.; Chaves, L.; Eadon, M.T.; Chang, A.; Quigg, R.J.; Alexander, J.J. Curcumin alleviates immune-complex-mediated glomerulonephritis in factor-H-deficient mice. Immunology 2013, 139, 328-337. [CrossRef] [PubMed]

211. Tapia, E.; Soto, V.; Ortiz-Vega, K.M.; Zarco-Márquez, G.; Molina-Jijón, E.; Cristóbal-García, M.; Santamaría, J.; García-Niño, W.R.; Correa, F.; Zazueta, C.; et al. Curcumin induces Nrf2 nuclear translocation and prevents glomerular hypertension, hyperfiltration, oxidant stress, and the decrease in antioxidant enzymes in 5/6 nephrectomized rats. Oxid. Med. Cell. Longev. 2012, 2012, 269039. [CrossRef] [PubMed]

212. Soetikno, V.; Sari, F.R.; Lakshmanan, A.P.; Arumugam, S.; Harima, M.; Suzuki, K.; Kawachi, H.; Watanabe, K. Curcumin alleviates oxidative stress, inflammation, and renal fibrosis in remnant kidney through the Nrf2-keap1 pathway. Mol. Nutr. Food Res. 2013, 57, 1649-1659. [CrossRef] [PubMed]

213. Tapia, E.; Zatarain-Barrón, Z.L.; Hernández-Pando, R.; Zarco-Márquez, G.; Molina-Jijón, E.; Cristóbal-García, M.; Santamaría, J.; Pedraza-Chaverri, J. Curcumin reverses glomerular hemodynamic alterations and oxidant stress in 5/6 nephrectomized rats. Phytomedicine 2013, 20, 359-366. [CrossRef] [PubMed]

214. Aparicio-Trejo, O.E.; Tapia, E.; Molina-Jijón, E.; Medina-Campos, O.N.; Macías-Ruvalcaba, N.A.; León-Contreras, J.C.; Hernández-Pando, R.; García-Arroyo, F.E.; Cristóbal, M.; Sánchez-Lozada, L.G.; et al. Curcumin prevents mitochondrial dynamics disturbances in early 5/6 nephrectomy: Relation to oxidative stress and mitochondrial bioenergetics. Biofactors 2017, 43, 293-310. [CrossRef] [PubMed]

215. Bugyei-Twum, A.; Abadeh, A.; Thai, K.; Zhang, Y.; Mitchell, M.; Kabir, G.; Connelly, K.A. Suppression of NLRP3 Inflammasome Activation Ameliorates Chronic Kidney Disease-Induced Cardiac Fibrosis and Diastolic Dysfunction. Sci. Rep. 2016, 6, 39551. [CrossRef] [PubMed] 
216. Correa, F.; Buelna-Chontal, M.; Hernández-Reséndiz, S.; García-Niño, W.R.; Roldán, F.J.; Soto, V.; Silva-Palacios, A.; Amador, A.; Pedraza-Chaverrí, J.; Tapia, E.; et al. Curcumin maintains cardiac and mitochondrial function in chronic kidney disease. Free Radic. Biol. Med. 2013, 61, 119-129. [CrossRef] [PubMed]

217. Hernández-Reséndiz, S.; Correa, F.; García-Niño, W.R.; Buelna-Chontal, M.; Roldán, F.J.; Ramírez-Camacho, I.; Delgado-Toral, C.; Carbó, R.; Pedraza-Chaverrí, J.; Tapia, E.; Zazueta, C. Cardioprotection by curcumin post-treatment in rats with established chronic kidney disease. Cardiovasc. Drugs Ther. 2015, 29, 111-120. [CrossRef] [PubMed]

218. Khajehdehi, P.; Pakfetrat, M.; Javidnia, K.; Azad, F.; Malekmakan, L.; Nasab, M.H.; Dehghanzadeh, G. Oral supplementation of turmeric attenuates proteinuria, transforming growth factor-beta and interleukin- 8 levels in patients with overt type 2 diabetic nephropathy: A randomized, double-blind and placebo-controlled study. Scand. J. Urol. Nephrol. 2011, 45, 365-370. [CrossRef] [PubMed]

219. Khajehdehi, P.; Zanjaninejad, B.; Aflaki, E.; Nazarinia, M.; Azad, F.; Malekmakan, L. Oral supplementation of turmeric decreases proteinuria, hematuria, and systolic blood pressure in patients suffering from relapsing or refractory lupus nephritis: A randomized and placebo-controlled study. J. Ren. Nutr. 2012, 22, 50-57. [CrossRef] [PubMed]

220. Sprecher, $\mathrm{H}$. The roles of anabolic and catabolic reactions in the synthesis and recycling of polyunsaturated fatty acids. Prostaglandins Leukot. Essent. Fat. Acids 2002, 67, 79-83. [CrossRef] [PubMed]

221. Hassan, K.S.; Hassan, S.K.; Hijazi, E.G.; Khazim, K.O. Effects of omega-3 on lipid profile and inflammation markers in peritoneal dialysis patients. Ren. Fail. 2010, 32, 1031-1035. [CrossRef] [PubMed]

222. Shing, C.M.; Adams, M.J.; Fassett, R.G.; Coombes, J.S. Nutritional compounds influence tissue factor expression and inflammation of chronic kidney disease patients in vitro. Nutrition 2011, 27, 967-972. [CrossRef] [PubMed]

223. Novak, T.E.; Babcock, T.A.; Jho, D.H.; Helton, W.S.; Espat, N.J. NF-кB inhibition by omega-3 fatty acids modulates LPS-stimulated macrophage TNF- $\alpha$ transcription. Am. J. Physiol. Lung Cell Mol. Physiol. 2003, 284, L84-L89. [CrossRef] [PubMed]

224. De Caterina, R.; Massaro, M. Omega-3 fatty acids and the regulation of expression of endothelial pro-atherogenic and pro-inflammatory genes. J. Membr. Biol. 2005, 206, 103-116. [CrossRef] [PubMed]

225. Corey, E.J.; Shih, C.; Cashman, J.R. Docosahexaenoic acid is a strong inhibitor of prostaglandin but not leukotriene biosynthesis. Proc. Natl. Acad. Sci. USA 1983, 80, 3581-3584. [CrossRef] [PubMed]

226. Needleman, P.; Raz, A.; Minkes, M.S.; Ferrendelli, J.A.; Sprecher, H. Triene prostaglandins: Prostacyclin and thromboxane biosynthesis and unique biological properties. Proc. Natl. Acad. Sci. USA 1979, 76, 944-948. [CrossRef] [PubMed]

227. Seki, H.; Tani, Y.; Arita, M. Omega-3 PUFA derived anti-inflammatory lipid mediator resolvin E1. Prostaglandins Other Lipid Mediat. 2009, 89, 126-130. [CrossRef] [PubMed]

228. Wiktorowska-Owczarek, A.; Berezińska, M.; Nowak, J.Z. PUFAs: Structures, Metabolism and Functions. Adv. Clin. Exp. Med. 2015, 24, 931-941. [CrossRef] [PubMed]

229. Surette, M.E. The science behind dietary omega-3 fatty acids. CMA J. 2008, 178, 177-180. [CrossRef] [PubMed]

230. Calder, P.C.; Yaqoob, P.; Thies, F.; Wallace, F.A.; Miles, E.A. Fatty acids and lymphocyte functions. Br. J. Nutr. 2002, 87, S31-S48. [CrossRef] [PubMed]

231. Vaughan, R.A.; Garcia-Smith, R.; Bisoffi, M.; Conn, C.A.; Trujillo, K.A. Conjugated linoleic acid or omega 3 fatty acids increase mitochondrial biosynthesis and metabolism in skeletal muscle cells. Lipids Health Dis. 2012, 11, 142. [CrossRef] [PubMed]

232. Arab, K.; Rossary, A.; Flourié, F.; Tourneur, Y.; Steghens, J.P. Docosahexaenoic acid enhances the antioxidant response of human fibroblasts by upregulating gamma-glutamyl-cysteinyl ligase and glutathione reductase. Br. J. Nutr. 2006, 95, 18-26. [CrossRef] [PubMed]

233. Kim, Y.J.; Chung, H.Y. Antioxidative and anti-inflammatory actions of docosahexaenoic acid and eicosapentaenoic acid in renal epithelial cells and macrophages. J. Med. Food 2007, 10, 225-231. [CrossRef] [PubMed]

234. Peake, J.M.; Gobe, G.C.; Fassett, R.G.; Coombes, J.S. The effects of dietary fish oil on inflammation, fibrosis and oxidative stress associated with obstructive renal injury in rats. Mol. Nutr. Food Res. 2011, 55, 400-410. [CrossRef] [PubMed] 
235. An, W.S.; Kim, H.J.; Cho, K.H.; Vaziri, N.D. Omega-3 fatty acid supplementation attenuates oxidative stress, inflammation, and tubulointerstitial fibrosis in the remnant kidney. Am. J. Physiol. Ren. Physiol. 2009, 297, F895-F903. [CrossRef] [PubMed]

236. de Mattos, A.M.; da Costa, J.A.C.; Jordão Júnior, A.A.; Chiarello, P.G. Omega-3 Fatty Acid Supplementation is Associated with Oxidative Stress and Dyslipidemia, but Does not Contribute to Better Lipid and Oxidative Status on Hemodialysis Patients. J. Ren. Nutr. 2017. [CrossRef] [PubMed]

237. Mas, E.; Barden, A.; Burke, V.; Beilin, L.J.; Watts, G.F.; Huang, R.C.; Puddey, I.B.; Irish, A.B.; Mori, T.A. A randomized controlled trial of the effects of $\mathrm{n}-3$ fatty acids on resolvins in chronic kidney disease. Clin. Nutr. 2016, 35, 331-336. [CrossRef] [PubMed]

238. Hung, A.M.; Booker, C.; Ellis, C.D.; Siew, E.D.; Graves, A.J.; Shintani, A.; Abumrad, N.N.; Himmelfarb, J.; Ikizler, T.A. Omega-3 fatty acids inhibit the up-regulation of endothelial chemokines in maintenance hemodialysis patients. Nephrol. Dial. Transplant. 2015, 30, 266-274. [CrossRef] [PubMed]

239. Panahi, Y.; Dashti-Khavidaki, S.; Farnood, F.; Noshad, H.; Lotfi, M.; Gharekhani, A. Therapeutic Effects of Omega-3 Fatty Acids on Chronic Kidney Disease-Associated Pruritus: A Literature Review. Adv. Pharm. Bull. 2016, 6, 509-514. [CrossRef] [PubMed]

240. Mori, T.A.; Burke, V.; Puddey, I.; Irish, A.; Cowpland, C.A.; Beilin, L.; Dogra, G.; Watts, G.F. The effects of omega-3 fatty acids and coenzyme Q10 on blood pressure and heart rate in chronic kidney disease: A randomized controlled trial. J. Hypertens. 2009, 27, 1863-1872. [CrossRef] [PubMed]

241. Barden, A.E.; Burke, V.; Mas, E.; Beilin, L.J.; Puddey, I.B.; Watts, G.F.; Irish, A.B.; Mori, T.A. n-3 fatty acids reduce plasma 20-hydroxyeicosatetraenoic acid and blood pressure in patients with chronic kidney disease. J. Hypertens. 2015, 33, 1947-1953. [CrossRef] [PubMed]

242. Ferraro, P.M.; Ferraccioli, G.F.; Gambaro, G.; Fulignati, P.; Costanzi, S. Combined treatment with renin-angiotensin system blockers and polyunsaturated fatty acids in proteinuric IgA nephropathy: A randomized controlled trial. Nephrol. Dial. Transplant. 2009, 24, 156-160. [CrossRef] [PubMed]

(C) 2017 by the authors. Licensee MDPI, Basel, Switzerland. This article is an open access article distributed under the terms and conditions of the Creative Commons Attribution (CC BY) license (http:/ / creativecommons.org/licenses/by/4.0/). 